ORNL/TM-2002/107

Environmental Sciences Division

\title{
Energy Efficiency, Building Productivity, and the Commercial Buildings Market
}

\author{
Donald W. Jones \\ David J. Bjornstad \\ Environmental Sciences Division \\ Oak Ridge National Laboratory
}

Lee A. Greer

University of Tennessee

Knoxville, Tennessee

May 8, 2002

Prepared for

U.S. Department of Energy

Energy Efficiency and Renewable Energy

Budget Activity Number EC 1701000

Prepared by

OAK RIDGE NATIONAL LABORATORY

Oak Ridge, Tennessee 37831

managed by

UT-BATTELLE, LLC

for the

U.S. DEPARTMENT OF ENERGY

under contract DE-AC05-00OR22725 


\section{TABLE OF CONTENTS}

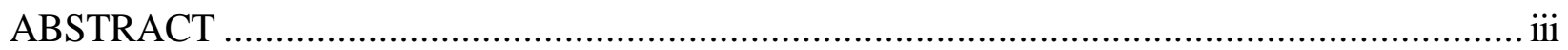

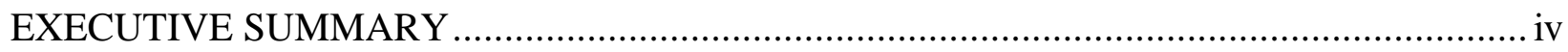

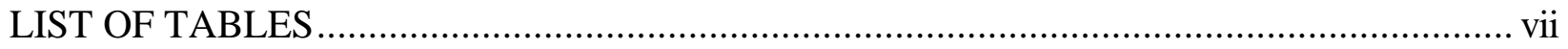

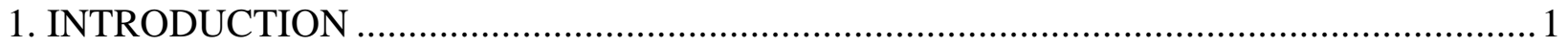

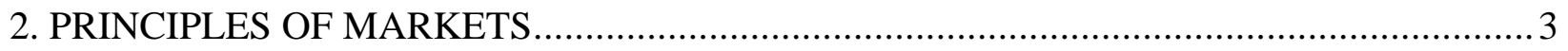

2.1. Supply and Demand in the Commercial Buildings Industry........................................... 3

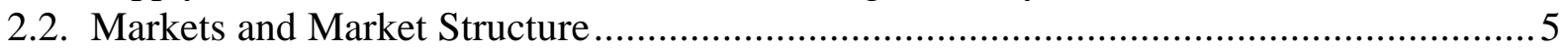

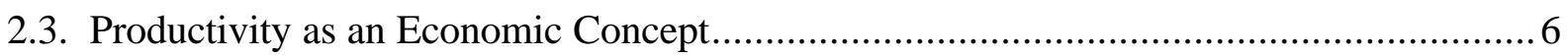

2.4. The Supply of and D emand for Characteristics of Products: Implicit M arkets

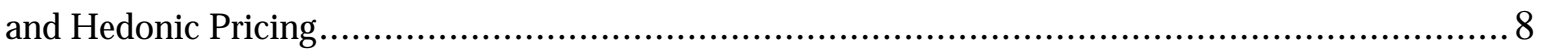

2.5 Buildings and Buildings Technologies as Investments ................................................. 9

2.6. The Influence of Financing on Investments in Office Buildings...................................... 11

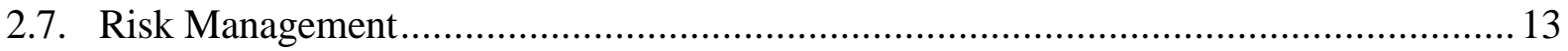

3. OVERVIEW OF THE COMMERCIAL BUILDINGS INDUSTRY ….............................. 14

3.1. The Actors and Institutions of the Commercial Buildings Industry ............................... 15

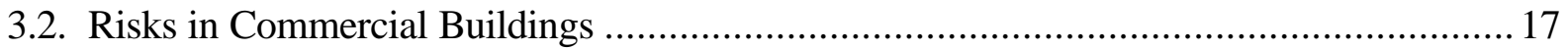

3.3. Economic Activity in the Commercial Buildings Market .............................................. 18

3.3.1. Size Distribution of New Commercial Buildings................................................. 19

3.3.2. Energy Efficiency Measures and Electricity use in New Buildings .........................22

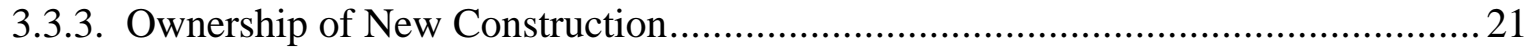

3.3.4. Component Cost Structure of Commercial Buildings ………….......................... 22

3.3.5. Energy Use in Office Buildings ........................................................................ 23

3.3.6. The Relative Magnitudes of the New Construction and Retrofit Markets ...............2 23

3.3.7. What Owners Want Compared to What They Have .............................................2 25

4. THE ENERGY-EFFICIENCY GAP IN COMMERCIAL BUILDINGS AND POLICY

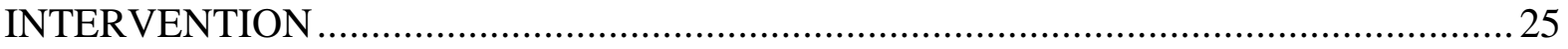

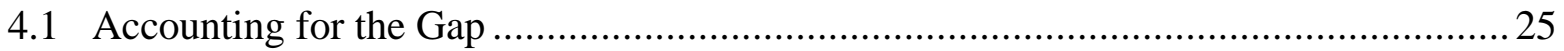

4.2. Policy Interventions in the Commercial Buildings Market ........................................22

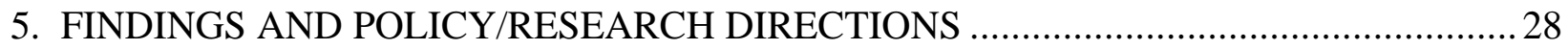

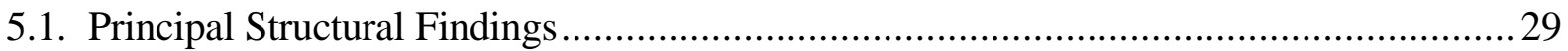

5.2. Energy Efficiency and Building Productivity: Opportunities and Needs .......................... 30

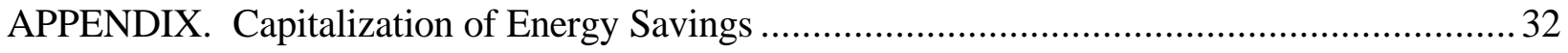

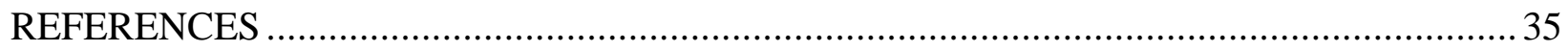




\begin{abstract}
The energy-efficiency gap literature suggests that building buyers are often shortsighted in their failure to apply life-cycle costing principles to energy efficient building technologies, with the result that under investment in these advanced technology occurs. This study examines the reasons this behavior may occur, by analyzing the pressures that market forces place on purchasers of buildings. Our basic conclusion is that the fundamental manner in which the buildings sector does business creates pressures to reduce initial capital outlays and to hedge against a variety of risks, including the ability of building owners to capture benefits from energy efficiency. Starting from the position that building buyers' willingness to pay drives choices over building attributes, we examine basic market principles, the structure of the buildings market, including the role of lenders, and policies that promote penetration of energy efficient technologies. We conclude that greater attention to buyers, and to the incentives and constraints they face, would promote a better understanding of building investment choices and contribute to better policies to promote the penetration of these technologies into markets.
\end{abstract}




\section{EXECUTIVE SUMMARY}

With considerable evidence that many economically profitable opportunities for deployment of energy-efficient building technologies are being missed in both new buildings and retrofits, the question remains - "Do buyers of buildings really ignore profit opportunities?" This report addresses that question by applying a broad-base market analysis to an apparent gap in deployment of energy-efficient building technologies in the commercial buildings industry. This approach is a departure from much of the literature that has identified this so-called energyefficiency gap. The energy gap literature has typically focused directly on choices over energy saving technologies, essentially isolating them from the remainder of the economic forces affecting the demand and supply for office space. It has found that agents evaluating those investment decisions use unreasonably high discount rates and employ first-cost investment criteria that do not consider the life-cycle operating costs of advanced building technologies. Among the explanations offered for this behavior are high transactions costs of evaluating individual building components, dispersed incentives within corporate bureaucracies, and a preference among building owners and lenders for first-cost investment criteria over life-cycle cost criteria. It tends to conclude that markets for these technologies are flawed and that buyers of commercial buildings would be better off if government put in place policies to promote or enforce their use.

Taking a broader market perspective, we advance the hypothesis that much of the slow pace of deployment may be accounted for by structural features of the commercial buildings industry such as (1) the fundamentally competitive nature of the building industry, (2) limited opportunities to enhance building productivity by using energy efficient technologies, a factor influenced by the cost shares of energy-related equipment and materials in construction and use, (3) a failure to recognize attributes of energy efficient technologies other than energy savings as potential contributors to building productivity, (4) market-driven pricing mechanisms for commercial buildings as large, complex physical assets, imposed by the financial industry on building buyers as credit conditions, and (5) the role of commercial buildings as an element of risk management within the national capital-market portfolio. This perspective offers alternative explanations for current deployment trends and suggests alternative policy targets if the need for government intervention is indicated.

The commercial buildings industry is composed of a large number of buyers and sellers who compete with one another. Such markets tend to be demand-driven, which is to say building buyers and owners are the final arbiters of the set of attributes a new or refurbished building will possess. Owners specify the features they want in new buildings, commission architects to design them, and contractors to build them. Because builders respond to buyers, buyers must perceive major opportunities to increase building productivity by using energy efficient technologies if builders are to have incentives to compete by innovating in the area of energy savings.

If energy-related capital and operating outlays were a large share of building construction and operating budgets, buyers of buildings would have special sensitivities to their efficient use, but these shares tend to be modest relative to other cost components. Maximizing investment 
returns on small components of large, complex assets contributes to overall building productivity, but it may not capture the foremost attention and imagination of building buyers.

Major energy-related components make up roughly 8-13 percent for HVAC and electrical systems in new construction and 4-18 percent in retrofits. Energy costs are about 4-5 percent of total user-costs of an office building. These shares are small relative to those of other key building components, and can be made to appear smaller by focusing attention on individual subcomponents of energy systems.

Energy-efficiency technologies, however, may have additional attributes that promote building productivity if they contribute to the comfort, health, or general well-being of a building's occupants. Evidence is emerging that a number of advanced building technologies that directly promise energy-savings results also confer such productivity benefits. Improved HVAC systems improve health of building occupants, reduce absenteeism, and appear to improve test scores in schools. Daylighting techniques have been found responsible for increasing sales by up to 40 percent in retail buildings, as well as improving students' test scores in schools. These are only a few of the many potential benefits from the new technologies. If these benefits can be documented and captured by the users who purchase them, and are of significant magnitude, building buyers will have additional incentives to consider energy-efficient technologies.

Focusing solely on the energy technology deployment decision tends to draw attention away from the larger economic forces that drive building investment decisions. The demand for commercial building floor space is a derived demand in the sense that space is an input to some larger productive process rather than an end in itself. The building industry thus values a building according to its contribution to that larger purpose. This contribution, which we term building productivity, is the basis of a building's value in the market place and of the credit that lenders will extend for its construction.

To the extent that energy efficient technologies contribute to productivity, either through energy cost savings or through value conferred by other desirable technical tributes, these contributions should be reflected in the building's price. Documenting these contributions to productivity, however, is difficult. Traditional methods of establishing building value focus on market norms and capitalized income, rather than on unique building attributes. Markets norms include the value of "comparable" floor space sales that may be quite incomparable to buildings with advanced energy technologies. Capitalized income calculations are dominated by larger components of income and cost. Market norms may in fact totally disregard energy savings if building owners pass these costs along to tenants. In the main, building owners or managers cannot ignore these market forces, because they are enforced by lenders or by outside directors responsible for stockholders' equity.

Moreover, if calculations of building value following construction are crude and difficult, calculations before the fact that serve as the basis of investment decision making are even more so. Taken as a single decision, the choice to build a commercial building is a choice made under considerable uncertainty. Thus, rather than using "best guess" estimates of key values, the decision making agent applies uncertainty analysis that tends to weigh negative outcomes more heavily than expected outcomes, which are the average of good and bad outcomes. These 
decisions are driven largely by income- and risk-related issues - tenancy and rental levels-with operation and maintenance (O\&M) costs still of concern but of lower priority. The riskcontainment focus of lenders reinforces this focus on income, since building income fluctuations have greater effects on note-payment capacity than do corresponding fluctuations in O\&M costs. Information on the revenue effects of advanced building technologies, as well as information on the ability of the market to capitalize these effects into prices, tailored to specific parts of the commercial buildings market, could induce owners, lenders, and appraisers to incorporate the characteristics of these technologies more fully into their calculations.

Moreover, risk management in the commercial building industry goes beyond risk management for a single building. Building owners typically own multiple buildings and lenders typically finance multiple buildings. Thus, the choice criterion is not only how the risk borne by a building affects that building, but rather how it affects the larger portfolio. Owners may reduce risk more cheaply by diversifying their portfolios of buildings than by investing in technology to reduce risks in individual buildings.

In sum, basic principles of markets apply to the commercial buildings industry. Buyers are willing to pay for additional perceived value, and sellers will respond to buyers' demands. Buyers will naturally focus their attention on the larger components of profitability. Buyers' perceptions of value are closely linked to building productivity. In additional to energy savings from advanced buildings technologies, buyers will place value on other technical attributes that improve worker productivity. Such values, however, are non-traditional and may not be easily captured by traditional real estate appraisal practices. Risk analysis tends to dominate the decision to invest. Lenders and buyers frequently control a number of buildings and treat them as elements in a portfolio for investment purposes.

Many of these influences have implications for policy analysis. For example, to the extent that buyers and lenders are key players in the decision to invest, they should also be principal targets of policies intended to promote deployment of energy saving technologies. Simply aiming policy activities at the builders, engineers, and architect may be insufficient. Buyers are oriented toward productivity and toward larger components of profitability. They may be more responsive to the bundling of energy technologies into larger systems, rather than the disaggregation of systems into smaller components. Market norms may exert considerable influence on individual investment decisions. Appraisal techniques keyed at "representative' buildings, for instance, may tend to undervalue buildings with advanced technologies. Finally, risks play a central role in business investment decision making and can cause decision makers to apply interest "hurdle" rates in excess of market rates and to seek payback periods of modest durations. These outcomes may have less to do with energy technologies than with the larger real estate market, and interpreting them as market flaws may obscure the underlying behavior.

The BTS technology road mapping activity positions DOE to learn more about the influence of this larger set of markets forces and their implications for DOE activities intended to promote the deployment of energy efficient technologies. By shining a spotlight on market 
forces, the road mapping effort provides an impetus to reexamine R\&D goals, to study relevant sources of uncertainty in more depth, and to learn more about the attributes that contribute to owner valuations of building productivity. 


\section{List of Tables}

Table 1. New construction and production input characteristics ...................................... 20

Table 2. Electricity consumption, by building activity.............................................. 21

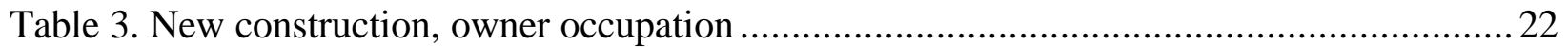

Table 4. Component cost shares in commercial buildings, 1986 (in percents) .......................... 23

Table 5. Shares of value in construction, 1992-1996 (in percents) ......................................... 24

Table 6. Shares of component systems in total value of additions, alternations, or reconstruction

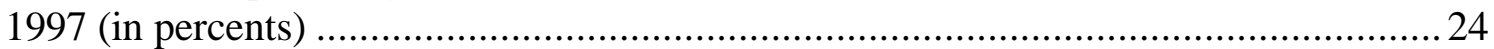

Table A1. Cash-flow analysis of alternative equipment specifications .................................... 34 


\section{INTRODUCTION}

The Department of Energy's Office of Energy Efficiency and Renewable Energy (EERE) has invested heavily in research and development intended to improve the energy efficiency of buildings at cost effective prices and has developed programs with the explicit purpose of transforming markets to accept these technologies, but virtually all studies of these activities conclude that significant opportunities for cost effective deployment of these technologies remain. So pervasive is this result that it has been given a name-the energy-efficiency gap. ${ }^{1}$ This gap suggests that a central decision maker charged with building construction could deliver buildings that save the nation energy and the building owner money, but that the markets supplying buildings fail to do so. A common conclusion is that government intervention can help bridge this gap, by regulating building practices and by providing information and demonstrations that document this missed opportunity.

As part of this larger effort EERE has undertaken a technology road mapping effort that places additional emphasis on the interactions between buyers of buildings and the agents who design and build them and on how these interactions affect building technology choices. The present report has been prepared in the spirit of opening the analysis to new insights that may arise from the road mapping process. There are benefits and costs to such an approach. On the benefit side, this approach offers the opportunity to observe better the context within which purchases of buildings take place. Ultimately, the choice of energy-related technologies must be integrated into this context rather than separated from it. The approach also allows a better assessment of the incentives that the various actors in the buildings industry face. Incentives do not dictate behavior, but they influence it and ultimately discipline poor choices. Finally, taking this approach allows us to draw on the rich body of literature describing incentives and behavior under market conditions.

The approach also has drawbacks. Principal among these is the necessity of abstracting somewhat from the extensive and informative base of technical information describing energyefficient technologies and the potential that they offer. It also muddies the waters by adding additional context and by losing the focus on energy-related issues in buildings relative to the nation's energy policy agenda. However, one must walk before one runs, and accept these losses, given that they are compensated through new insights. Ultimately, the technical details can be fully integrated as well.

All in all, this is a tall task, and the purpose of this paper is to provide the overall logical framework guiding the larger activity. Subsequent papers of this project will take up important topics of decision-making processes and productivity measurement in more detail. We approach the current purpose in four steps. In section two, immediately below, we take up the issue of incentives and market behavior. In general, larger numbers of buyers and sellers are characteristic of markets in which buyers play the dominant role in determining the specifications of the

\footnotetext{
${ }^{1}$ Shama (1983) labeled the phenomenon the "high efficiency/low adoption paradox." In general the notion is that much unadopted technology is cost-effective at current prices (Jaffe and Stavins 1994, 92). The literature has contained considerable debate on the proportions of the low or slow adoption of the new technologies attributable to market failure and to ordinary but slow workings of the market.
} 
products they purchase. In the case of commercial buildings, most buyers obtain space to meet the needs of their dominant economic activity, rather than as an end in itself. Thus for the owneroccupant, the demand for office space is derived from the demand for the firm's product, while for the firm that rents space as a business it is the demand for commercial space by others. We pursue this topic by discussing the general nature of intrafirm decision-making, the special issues associated with the purchase of a durable asset, and the economic concept of productivity. We then introduce the notion that buildings can contribute to productivity in multiple ways and discuss some evidence that supports this conclusion.

In section three, we provide a broad overview of the commercial buildings industry and present data that describe its salient features. ${ }^{2}$ The principal observation from this exercise is that the industry is diverse, but with several striking uniformities. Generally, there are large numbers of sellers and buyers, a circumstance that militates against the accumulation of market power by any one player and tends to concentrate decision making in the hands of buyers. Second, the financial risks involved in construction and ownership of large commercial buildings are considerable, and the national capital market is used as the principal vehicle for managing ownership risks, a fact that may be important in the analysis of energy-efficiency investments in individual buildings. Third, the cost shares of energy-efficiency technologies in new and retrofit construction are small, as are the energy cost shares in building user costs. They are even smaller if these components are dealt with individually, rather than as an energy package. Finally, there is evidence that building tenants are satisfied with their current levels of energy efficiency and environmental cleanliness but nevertheless remain interested in productivity-enhancing features.

In the fourth section, we discuss the evidence for the efficiency-gap hypothesis, the programs government has adopted for dealing with it, and the implications of our discussion in previous sections for alternative modes of intervention. In the final section, we return to the commercial building technology roadmap and integrate our findings with it. We then identify special topics that require additional attention, the kinds of analysis we will pursue, and data needs to support analysis.

Ultimately, our goal is to pursue the implications of two topics. First, from this analysis, we develop the hypothesis that the decision making process of the firm within the market context of its business process is different from that of the isolated consideration of building technologies. Of particular consequence is the manner in which firms treat uncertainty. Second, we hypothesize that there indeed exist multiple attributes of buildings that contribute to firm productivity. We further describe the types of measurement that would be useful and the alternatives for obtaining them.

\footnotetext{
${ }^{2}$ Government buildings, including schools, are, properly speaking, not commercial buildings. The motivation of their owner is not the straightforward, reasonably easily measurable profit of the business owner of a commercial building. Administrative procedures governing investment in public buildings may attempt to replicate the economic efficiencies that markets generate, but are not as responsive to opportunities as markets permit private agents to act. Investment behavior in public buildings would comprise a separate research topic.
} 


\section{PRINCIPLES OF MARKETS}

Markets are institutions that facilitate interactions between buyers and sellers that ultimately lead to transactions, in this case the construction and sale of commercial buildings. By applying concepts of microeconomic theory, one can abstract from specific, anecdotal evidence, as would be gained through the study of individual buildings, and generalize about the kinds of behavior that characterize the various market participants. The most basic concepts in market analysis describe the behavior that determines building costs and attributes-actions of the architects, engineers, and builders - and the value placed on building attributes - by the buyers/owners, tenants, and lenders. We refer to these concepts as supply and demand, respectively. Subsection 2.1 discusses the behavior of agents in these two roles. These two groups interact in ways that are predictable but that are influenced by characteristics of the products involved and the institutions that have arisen to deal with special aspects of those products.

Subsection 2.2 describes how markets work to resolve the inherent rivalry between suppliers and demanders. Basically, buyers want the most value relative to building prices and sellers want the lowest costs for any given building price. Each seeks to improve his or her net revenue position and in doing so, reduces the net position of the other. Interactions between technologies and people in the market place are responsible for the productivity of both, and productivity effects of new technology can affect the prices of the buildings in which they are deployed, as subsection 2.3 explains. Subsection 2.4 takes the market interaction involving entire buildings to the level of individual characteristics of buildings, such as the type of technologies they contain in various functional and structural systems, using the concepts of the implicit market and hedonic prices. In the case of commercial buildings, the products are large, complex, immobile, and expensive, and impose a number of financial risks on both their owners and their producers; subsection 2.5 accordingly discusses the implications of some important characteristics of investments. Intricate institutions have developed to manage the risks associated with them, by both linking their financing to national and international capital markets and making their intricate characteristics as transparent as possible. Subsection 2.6 discusses the significance of financing institutions and practices for the technology that gets deployed in a building. The final subsection discusses risk management strategies in commercial buildings.

\subsection{Supply and Demand in the Commercial Buildings Industry}

Commercial buildings are large, complicated products with many optional features. Even the smaller commercial buildings are complex products and are more costly than many items that businesses routinely purchase. They also are intermediate products, in the sense that people, or firms, demand them not for final consumption but so they can help create a final product or service. As a result, the value buyers place on a building is closely linked to the value of the building in production, where production could include office functions, education, health functions and the like. For this reason markets are said to be "demand-driven." The values of the component choices available in designing buildings are also measured in terms of their separate contributions to the profits of the firm using the building. Different firms may value particular building features differently because they contribute differentially to each firm's productivity. Thus, for a firm to decide to use some advanced technology in a building, at an additional cost 
over a more common alternative, it will have to be satisfied that the difference in cost will contribute at least that much to its profits, through higher revenue, lower cost, or both. Market demand is often described as a continuous relationship between the price and quantity of building floor space, but this relationship is more properly described as the aggregated set of values that individual buyers place on floor space, which in turn is dependent on the specific use to which the firm will put the floor space. Whereas there is no rigid definition of a market's boundaries, market institutions typically provide de facto market boundaries. Thus, the value buyers place on buildings is closely related to a number of related factors, such as the availability of capital to finance the building's purchase, which is in turn dependent on the appraisal by the lender of the accuracy of the value estimates the building's buyer prepares.

The supply of new buildings is the set of new buildings of differing attributes that could potentially be produced relative to the costs of producing each specific attribute combination. In general, suppliers are prepared to produce buildings of higher attribute quality at higher prices. The supply side of the building industry is essentially responsible for creating technical alternatives, which buyers, in turn, may evaluate in choosing which buildings to buy. But suppliers are not responsible for the ultimate choices, other than in the indirect sense that they make alternatives available.

Changes can take place in both supply and demand relationships. On the supply side, technologies can change, materials costs can change, and government regulations can make production more costly, possibly by setting quality standards for specific equipment or materials. On the demand side, the demands for the products produced by the buyers can change, or the perceived or actual usefulness of the building in producing the tenant's product may change. When firms rather than individuals are the demanders of a product, as in the case of commercial buildings, changes in the demands for their final products - say, legal services or retail goodswill precipitate changes in their demands for the goods they use to make those final products, including building office space and its quality. Again thinking of commercial buildings, if the productivity of some type of equipment were to increase, the entire schedule of demands for it would rise. At any price of the equipment, buyers would consume more of it, or equivalently, they would be willing to pay more for any quantity than they would have been previously. The same effect would be produced by a change in the perception of the equipment's productivity, assuming that the new perception were correct.

The ability of buyers and sellers to substitute helps to reconcile the rivalry between buyers and sellers. When several similar products are available, the one with the lowest price will attract the greatest demand and experience the greatest sales. When several varieties of a product coexist in the market, if the price (cost) of one variety increases, some of its consumers will switch over to a competing variety whose price has remained lower. And similarly when the price of one variety falls, it will attract customers who previously would have used one of the other varieties. This form of competition will eliminate any above-normal profits that the maker of any particular variety can earn. Such variety in the buildings market would be represented by different features and qualities, in terms of energy efficiency and the use of advanced equipment and materials that are considered to affect productivity. 
Although both supply and demand are important in determining prices and quantities of goods bought and sold, their roles are distinct. Buyers specialize in some other activity and employ buildings in that activity whereas sellers specialize in producing buildings and are responsible for introducing technical innovations to buyers. In some markets, firms compete with one another on the basis of advances in the state of technology. Consumer electronics and computer software immediately come to mind as currently prominent examples of industries in which firms have offered competing products that serve much the same purpose, but niche markets for advanced fishing reels and suitcases also exist. We argue below that technological competition seems to be less prevalent in the buildings industry, but were its presence to increase, the energy efficiency of buildings could benefit.

A unique aspect of buildings and their components is that they are durable assets and buyers expect to receive a stream of future benefits in exchange for a current commitment to purchase. The fact that commitments are current and benefits accrue to the future means that buyers' estimates of value must be forecasted, a process that is of necessity uncertain. Managing this uncertainty is a far more complicated process than merely making a best guess and can significantly shape the institutional character of building markets.

\subsection{Markets and Market Structure}

Markets reconcile buyers' wants and sellers' capabilities by providing institutions through which the substitution of attributes of various costs to producers and of various values to buyers can be reconciled on a building-by-building basis. For any given building the price at which exchange occurs reflects the value of the product to the consumer and an approximation of production cost to the supplier. This price/building combination is sometimes referred to as a competitive equilibrium.

Market structure is essentially the number of buyers and sellers participating in a market, and its importance derives from the fact that these numbers in any particular market determine the type of competition that occurs in that market. In markets that have large numbers of both sellers and buyers, and products are similar or standardized, no seller and no buyer believes - from their experience-that they have any influence on the market price of the product they make or buy. The best strategy for producers in competitive markets to increase their profits is to produce their buildings at the lowest price they can achieve and to sell as many buildings as they can. This price must produce sufficient revenue to let producers make their payrolls, cover materials and other costs, and leave a residual to the owner/entrepreneur that compensates him or her for the risks they take by staying in the business instead of going to work for someone else. A market like this is called perfectly competitive.

The commercial buildings industry roughly fits this description of a competitive market structure. In 1997, the United States had 92,710 A\&E firms (of which 20,602 were purely architectural firms and 52,526 purely engineering firms), 30,817 general contractors specializing in nonresidential buildings other than industrial buildings and warehouses, and 30,218 HVAC firms. ${ }^{3}$ Even spread over fifty states, this is a large number of firms, and buyers can pick and

\footnotetext{
${ }^{3} 1997$ Economic Census, Construction Industry Series, Table 1 of respective NAICS classsifications.
} 
choose among enough of them for any particular job to get very close to the lowest possible price for a given set of building specifications. If one supplier were to attempt to offer the good for a slightly higher price, a buyer could get the product he or she wanted for a lower price from another seller; before long, buyers would cease to call on that builder, and he would exit the industry for want of profits if he did not bring his costs down. These conditions characterize a large portion of the commercial buildings market — much of the highly standardized, smaller buildings (1,000-10,000 square feet) which account for 83-85 percent of new buildings and 25-30 percent of new floor space, and a good proportion of another 10-12 percent of new buildings and corresponding 10-25 percent of new floor space in buildings up to 50,000 square feet. ${ }^{4}$ Firms in competitive industries are highly constrained in their ability to earn profits beyond the normal, market rate of return on the capital equipment they use. They have little financial flexibility to engage in $\mathrm{R} \& \mathrm{D}$ to improve their products or their production techniques and instead direct their improvement efforts at reducing their own production costs.

Other market structures are more conducive to R\&D. Privately financed R\&D may occur in oligopolistic industries - those with a small enough number of sellers that each can influence the price of the product they sell. For example, there is a smaller number of HVAC equipment suppliers than construction firms and these suppliers may try to compete through R\&D. But, even the R\&D conducted by equipment and materials manufacturers is selected with an eye to what demanders - building owners — want and are willing to pay for. As Howarth and Andersson (1993, p. 264) noted in passing in an article on residential retrofits, "Equipment producers have no direct incentive to produce efficient devices and will do so only to the extent demanded by consumers." The same can be said about the firms that produce equipment and materials for commercial buildings.

Specialized buildings like large office buildings are often sold in matching markets, one in which a unique product is bought and sold. In these circumstances, the potential exists for significant technical innovation, depending on the value of the building to the buyer's business. Custom design of large buildings is possible, but often highly costly. Sometimes buyers seek to combine the advantage of custom design and standardization, by working out a specific template and repeating it in numerous applications. Franchise businesses like fast food restaurants carry out this practice, as do any number of retail and commercial industries.

While some building firms do seek to serve niche markets, there is little evidence of buildings contractors having such unique capabilities that they can monopolize some portion of

\footnotetext{
${ }^{4} \mathrm{~A}$ variant on the perfectly competitive market is the monopolistically competitive market, a characterization that may fit the larger end of the size distribution of $A \& E$ and general contracting firms, but ultimately has little consequence on the principal conclusions here. In monopolistic competition, a number of varieties of the same basic good can be produced, and each variety has its following among some group of consumers who prefer that variety to others, at least as long as the price spread does not get too wide. Price competition among varieties eliminates all "economic profits" (any profits above the market rate of return on capital) that monopolistically competitive producers can make, which also eliminates most opportunities for R\&D on their part. It is possible that very large, complex commercial buildings, which are built by the largest of the general contracting firms - and designed by the largest of the design firms - may fit this description of "variety on a basic theme," with the variety taking the form of architectural distinctiveness as well as some qualitative differences in functional specifications. It is possible that there are some small, niche markets at this end of the distribution of commercial building sizes, and that some of the largest firms may compete on the basis of corresponding specializations, but it is not clear that technological innovativeness forms an important margin of competition even among these firms.
} 
the market. There are simply too many contracting firms nationwide, and there is sufficient interregional mobility in the work they are willing to undertake, that competition comes to the aid of the buyer.

\subsection{Productivity as an Economic Concept}

Productivity refers to the contribution to value that an input to a production process offers. Firms hire labor because of its productivity, and the amount of labor a firm hires depends on how productive the labor is relative to the wage it must be paid. The same principle applies to the equipment and materials that a firm uses. The equipment-everything from office furniture to forklifts-helps the firm produce value. It can help the firm produce a greater amount of its good or service, the value of which is at least as great as the cost of the equipment rental. For firms, value means profits, so we can say that firms use labor and capital because they contribute to the firm's profits, after the firm has paid for their services. Productivity is the source of a firm's demand for these inputs, and of course, buildings and characteristics of buildings are among its inputs, alongside workers and equipment.

Inputs can contribute their productivity to a firm's profits in several different ways. The first major alternative is by increasing the quantity of goods or services that the firm can produce, holding the quantities of all other inputs constant. The second principal route to providing productivity is to reduce costs of other inputs. For example, air conditioning, compared to no air conditioning, can improve the reliability of performance of sophisticated electronic equipmentreducing the needs for maintenance, repairs, and replacement. It can make workers more comfortable, particularly in hot or humid climates, permitting them to focus on their jobs.

Firms may compete for workers by offering on-the-job amenities in addition to direct cash compensation. Potential workers may be as swayed by the physical attractiveness or the amenities attendant to their place of work as to additional increments of cash income. Employers may find they can attract workers with building amenity expenditures that are smaller than the required salary increments needed to attract them into a "standard, no-frills" building. This wage-cutting effect, however, requires qualification. Happier workers, or more empowered workers, need not be more productive workers, nor need they be willing to take pay cuts. ${ }^{5}$ It is strictly an empirical matter whether the building characteristics offset the cost of those additional features. The same caveat applies to what has been called the "productivity effects" of energy-efficient building technologies. Again, the issue is the empirical one of whether the productivity effect of what we may call subsidiary benefits from energy-related technologies is large enough to pay for the incremental change to the building.

There is, in fact, anecdotal evidence that energy efficiency measures do tend to enhance the productivity of business activities conducted in buildings. Although the correlation is not well or extensively documented, this productivity effect is sufficiently well known to appear in

\footnotetext{
${ }^{5}$ These need not be actual reductions in a paycheck, but are far more likely to be the acceptance of a lower wage than would otherwise be required or, possibly, acceptance of a period of slower pay increases which, when it resumes its "normal" growth rate, leaves the firm's payroll growing from a smaller base than it would have been otherwise.
} 
textbooks used in architecture (e.g., Morton and Jaggar 1995, 245-246). Three examples have been reported recently, one from a for-profit firm and two from schools, for which the economic productivity is harder to measure because educational output is not measured in simple dollar terms. First, the use of skylighting in a retail store chain was associated with 40 percent higher revenues than in stores without skylighting (Heschong et al. 1999a). Second is a study of improved air flow in schools with new HVAC systems. Here, absenteeism fell by $40-50$ percent (Bayer et al. 1999). It is estimated that an increase in attendance rates of as little as 5 percent could draw sufficient state funds to pay for an upgrade of this kind. The third case is one of daylighting in schools, a study of 21,000 student records in California, Washington, and Colorado. In this instance, improvements of 5-25 percent in reading and math tests were associated with daylighting and windows that could be opened (Heschong et al. 1999b).

Measuring the productivity of specific components of a building is a topic in its own right, and the next section introduces the principal method of identifying those effects.

\subsection{The Supply of and Demand for Characteristics of Products: Implicit Markets and Hedonic Pricing}

For building buyers to take full advantage of the subsidiary benefits of energy technologies they must have better estimates of the scale of these benefits relative to their costs. Making these measures is difficult because they are subtle and intertwined with other aspects of the firm and its management system. One tool of analysis that may help unbundle these effects is the hedonic demand model, which has been used to identify the productivity effects of a number of economic inputs, including buildings. ${ }^{6}$ The empirical implementation of this approach can help to identify the incremental value of, say, an advanced HVAC or fenestration system on either the value of a building or on its square-foot rental prices.

Many products in our society are complicated, heterogeneous combinations of devices that deliver services in different quantities or qualities, in contrast to relatively homogeneous commodities, such as grains, bulk chemicals, and so on. These products include residential housing, motor vehicles, and household appliances, as well as commercial buildings. The hedonic model has emerged to analyze the demands for these products as the sum of the demands for the specific characteristics they possess. Thus, to study the market for commercial buildings, the hedonic demand, or hedonic pricing, model can be used to separate the demand for the overall building into the demand for the specific characteristics of its components. Just as in the market equilibrium for a homogeneous commodity, the equilibrium price of supplying a given amount of some set of characteristics (square footage, cubic feet per second of air flow through an HVAC system, type of fenestration system) in a commercial building will be equal to the amount buyers are willing to pay for the combination. By developing data sets with variability among the component attributes, the approach permits estimating the demands for the components as if there were separate markets for each component. Despite the inherent difficulty of the technique,

\footnotetext{
${ }^{6}$ The concept of hedonic prices for characteristics of products, ranging from the feel of a toothbrush handle to the looks of Apple Computer's new Power Mac G4 Cube, has entered the popular press with Postrel (2001) in The New York Times.
} 
including data requirements, statistical procedures, and the need to interpret the results within context, the approach offers potential to gain insight into this difficult problem. (Rosen 1974).

The hedonic model has been used widely in the analysis of residential housing markets, including the capitalization of the value of energy-efficiency retrofits in them (Palmquist 1984; Longstreth et al. 1984; Mills and Simenauer 1996). A smaller number of studies has used the hedonic model to study the effects of local amenities, a limited number of building characteristics, and location within a metropolitan area on the values and rentals of commercial and industrial buildings (Mills 1992; Wheaton and Torto 1994; Sivitanidou and Wheaton 1992; Sivitanidou 1995, 1996; Lockwood and Rutherford 1996). Even the market valuations of some architectural features in commercial buildings have been elucidated with this method (Vandell and Lane 1989).

The hedonic demand model is a tool for conceptualizing and empirically identifying the separate valuations of different components of multi-attribute products such as buildings, but buildings are capital assets, whose purchase involves an investment. The following section introduces the issues involved in investing that make those expenditures more complicated than spending decisions for current consumption.

\subsection{Buildings and Buildings Technologies as Investments}

Past investigations of the deployment of energy-efficient building technologies have relied, implicitly or explicitly, on a specific behavioral investment model to simplify their analysis. Concepts such as cost-effectiveness hinge on one's interpretation of optimal investment decision making. While we appreciate the need to simplify analysis, it is important that the conclusions of an analysis be driven by the behavior of the investors, rather than the model assumed to describe their behavior. Thus, it is useful to view the investments in buildings technologies in the larger context of investments in entire commercial properties. This section emphasizes the anticipatory character of any investment, the relative magnitudes of uncertainties commercial building owners and lenders must manage, and the distinction between uncertainties in energy prices and technology performance. Each of these contextual matters points to the criticality of owners' demands and the quality of information.

A decision to purchase a building is a decision to purchase a durable asset that will return a flow of benefits over a period of the future. The decision the buyer must evaluate is: What current cost is justified, given the timing and uncertainty of the future flow of benefits? Commercial buildings themselves may continue to be economically viable for fifty to one hundred years or longer, and many less durable components are expected to last twenty to thirty years. An investment requires the buyer to commit today to an outlay based on the anticipation that benefits will be derived in the future. The purchase contract obligates the buyer to a known, and generally relatively inflexible, stream of mortgage payments that must be more than covered by the income generated by the building. In the case of retrofitting an existing building with one or more component systems to improve energy efficiency, the present value of the expected reduction in operating costs must be sufficient to cover the cost of the new system and its installation. If agents in the market hold this expectation, they will capitalize the value of the operating cost reduction into the price of the building. That is, the value of the building will rise by the present discounted value of the operating cost savings less the incremental cost of the technology. 
Appendix A offers a numerical example of how capitalization works, in terms of the cash flows of an office building. It also demonstrates the practical importance of first cost even if people use a life-cycle cost approach to evaluating advanced technologies: interest costs on the investment drive a substantial difference between gross and net capitalized value of the savings.

Projecting future time paths of revenues and costs for a new building involves the risk that the projections may be wrong. If errors in the projections are sufficiently large they could compromise the financial integrity of the buyer and his or her ability to repay their lender. The principal source of risk faced by building owners is variability in rental income. For a building actually used by its owner, the corresponding risk would be uncertainty in the demand for the firm's product. Projections of operating costs have uncertainties attached to them as well, but operating costs account for only about 30 to 33 percent of rentals, and total utility costs (including water) account for only about 30 percent of operating costs; the energy share in overall office building user costs is even smaller (4-5 percent) (BOMA 2000b, 25). Despite occasional spikes, the energy price series does not have a particularly high variance. ${ }^{7}$ In contrast, vacancy rates in commercial buildings and the square-foot rental rate on building floor space exhibit considerable variability. ${ }^{8}$ Rental income is the product of occupancy rate and the rental rate on floor space, either of which may vary. The covariance between the vacancy rate and the rental rate is negative, so the coefficient of variation of rental income will be larger than that of either of its components. Investing in energy-conservation equipment that is uncorrelated to revenue components may not be an attractive market option. Owners, as well as property management firms, are more interested in stabilizing rental and lease income than in energy management, because they can contain a larger fraction of the net income risk they face by targeting the principal revenue inflow than in a small component of operating costs (BOMA 2000a, 26-33).

When evaluating a new type of equipment or material for installation in a building the owner is most likely to be concerned with the effectiveness of what may be an "unproven" technology, rather than with the future time paths of oil, gas, and electricity prices. "Waiting to see" will not accomplish anything in terms of clarifying the uncertain future regarding energy prices, because whatever undesirable scenario does not happen during the waiting period could just as well happen after the waiting period. With the performance of technology, the waiting period has a meaningful terminal point, because it clarifies the effectiveness of the technology. These considerations are addressed by the theory of investment under uncertainty, the dominant behavioral model in use by investment theorists. This model has also been used to study the slow

\footnotetext{
${ }^{7}$ From Sanstad et al. (1995, 740), the coefficient of variation (standard deviation divided by the mean) of the energy price from 1955-81, across both 1973 and 1979-80 oil supply shocks, is 2.58 . Using untransformed oil prices is inappropriate to measure the element of surprise in oil price movements across this period of the two oil supply shocks. Much research has been conducted into satisfactory measurement of the surprise element in any statistical measure of oil price volatility; e.g., Hooker 1996; Hamilton 1996).

${ }^{8} \mathrm{We}$ do not have mean and standard deviation data on these two variables, but the sense from the literature is that the volatility of both is considerable: e.g., Morton and Jaggar (1995, 340-341) on office vacancies and rents in London in the late 1980s and early 1990s; and Hendershott (1996, 58 Figure 1, 61 Table 2) on rental rates (1970-92) and vacancies (1985-92) in Sydney.
} 
deployment of energy-efficiency technologies in both commercial and residential buildings. ${ }^{9}$ In cases in which owners could defer the choice of a particular technology specification until more information became available on it, an option value arises to waiting, and that option value is a real cost to current investment, just as are the purchase and installation costs. This additional cost to the current investment would require the building investor to anticipate getting a higher rate of return on the building than he should appear to be satisfied with if an observer looked only at the equipment and installation costs and the potential energy savings they could deliver. ${ }^{10}$

This theory has been applied to the overall investment in office buildings in the United States from 1982-1998, with the uncertainty coming from the variability in demand for the office buildings themselves (Sivitanidou and Sivitanides 2000). Although the implied increase in the discount rate contributed by the uncertainty was not calculated, investors apparently paid more attention to the uncertainty about demand for office space after the office market crash of the late 1980s than before the crash, paying less attention to rental income cash flow and tightening construction projects to be smaller and completed within shorter time periods. Greater caution about deploying new technology in commercial construction projects could accompany such a generalized financial tightening. Lentz and Tse (1999) find that demand fluctuations in the goods market work backward quickly into the demand for commercial real estate and emphasize that real estate/space supply responses are always made under demand uncertainty. The uncertainty that raises the required rate of return on energy efficiency investments in buildings need not be restricted to uncertainties specific to those technologies, as the energy conservation literature has implicitly assumed.

\subsection{The Influence of Financing on Investments in Office Buildings}

Financial management is for practical purposes, risk management, a circumstance that extends fully to lending for commercial building construction. Although appraisers are trained to take account of many energy-efficiency features of buildings, the principal subject of investigation is rental stability.

Several agents participate in evaluating an office building loan, including the owners themselves, banks, insurance companies, pension funds, and appraisers. The principal subjects of investigation in a proposed office-building loan are location and "utility," the ability of an office building to satisfy specific tenancies and types of tenancies over time. Lenders typically extend their cash-flow analyses up to ten years beyond the mortgage period (which itself can extend to

\footnotetext{
${ }^{9}$ Hassett and Metcalf $(1992,1993)$ used this model in the evaluation of residential energy efficiency investment, with uncertainty located only in the energy price forecast, and reported that the option value could account for the unusually high discount rates consumers appeared to be requiring for these investments.

${ }^{10}$ Sanstad et al. (1995) reworked Hassett and Metcalf's problem and reported results that the option value was insufficient to account for the observed discount rates. According to their results, the variance of the uncertain variable (the energy price in their case) perceived by the investor would have to be six times the size of the variance in the energy price to push up the option-inclusive discount rate (what they call the hurdle rate) to the lower end of discount rates imputed to consumers of energy-efficient appliances. The energy price is not a particularly high-variance series, and technology performance uncertainties, based as they are to a large extent on the absence of reliable, field performance information conceivably could give variances of that magnitude or larger.
} 
40 years, although $25-30$ is more common), and stability and predictability of tenancies is an important consideration. The cash-flow analyses of both lenders and appraisers compare the relationship between net operating income (revenue minus operating expenses) and the debt service on the permanent loan. However, communication technologies have reduced locational premiums for office activities. Decreased locational advantage increases the occupancy rate variability used in the income component of the cash-flow analyses, and consequently adds pressure to minimize first-costs in the building's construction (Steele and Barry 1993, 432). During slack market periods, appraisers in particular rely less on the discounted cash flow method of evaluation and look instead to first-year income and expenses and capitalize future net income at one to two percentage points above the prevailing market rate (Steele and Barry 1993, 427).

Because the construction period is subject to unique risks, construction loans are separated from ownership loans. Construction loans are made by a smaller array of lenders and also are financed at higher rates than permanent loans. Construction loans typically include preleasing requirements, sometimes as high as 70 percent (of space rented), and requiring as much as 50 percent of a building's leases to be long-term (ten years or longer). Commercial banks are willing to underwrite construction loans of between 65 and 75 percent of cost (occasionally going as high as 85-90 percent during boom times and falling to the 55-60 percent range during recessionary periods such as the early 1990s) (Steele and Barry 1993, 420-422).

For the permanent loan, a different set of lenders uses a wider array of criteria to evaluate the same market information as those used for the construction loan, a practice that can result in quite different results (Steele and Barry 1993, 422). Whereas lenders evaluating construction loans want to ensure the project will get off properly, lenders evaluating ownership loans are concerned about the long-term prospects of the project. Appraisers and lenders both tend to be skeptical of the reliability of energy savings projections (Chao et al. 1998). While recognizing the importance of "quality" in an office building for its ability to attract and retain tenants, they are equally sensitive to the inevitable ups and downs of local economies, recognizing that buildings tend to be built when times are good but that mortgage payments must be covered during slack times as well (Coverdale 1993, 440-441).

There do not seem to be any systematic investigations into the effects of recent technological developments on the "financability" of commercial buildings, but we have been able to glean some rather scattered anecdotal evidence on the types of effect that might be found in more systematic study. Government regulations governing a number of design elements affecting energy use "have added substantially to construction costs in office buildings" (Brennan 1993, 251). HVAC systems compete directly with rentable space in office buildings, and systems that offer greater local control and provide greater comfort and flexibility to users add to first costs. Alternative methods of providing more local control trade off lower first costs with higher maintenance costs. The increased size of mechanical systems in modern office buildings ${ }^{11}$ have increased the sound generated from that equipment and demand corresponding design responses for acoustical isolation. Double glazing of windows, required for energy efficiency have the

\footnotetext{
${ }^{11}$ On the other hand, as more efficient buildings require less heating and cooling equipment, they may need more ventilation equipment to use natural cooling. The net effect on first costs remains an empirical question.
} 
serendipitous capacity to reduce street noise however, contributing a functionality that may be more noticeable to users (Brennan 1993, 251, 256-260). Sai-Chew et al. (2000, 325) observe that the commercial building design that produces the greatest energy savings tends to be quite different from the design that yields the greatest cost saving. Kolderup et al. $(2000,197)$ believe that the science of energy-efficient buildings is better able to provide energy-efficient buildings than the technology for describing the energy efficiency of buildings is able to furnish easily understood and reliable information that appraisals could use to support financing.

Risks are important characteristics of investments, but the methods investors use to manage the risks associated with any particular investment are not always straightforwardly or exclusively focused on the investment under review. The following subsection explains some principles of risk management as applied to the commercial buildings sector.

\subsection{Risk Management}

A substantial portion of commercial buildings - in the range of 20-30 percent by value-is securitized into the national capital market. That is, they are owned as part of the national-and international—capital market. Evidence exists that price discovery occurs in this portion of the commercial buildings market, which is informationally more efficient than the unsecuritized portion, and that the information produced in the securitized portion is transmitted to the latter over the next one to three years (Barkham and Geltner 1993). The implication of this securitization is that risk management becomes a portfolio task involving rates of return, and variances of those rates, on entire portfolios rather than an individual-building task focused exclusively on the volatility of net operating income on each individual building. The holder of a portfolio of buildings also is concerned with the rate of return, and its volatility, of the entire portfolio of buildings rather than with those two indicators for any particular building. However, he is likely to be interested in the correlation between the rates of return on different classes of buildings and between individual buildings and the rest of a portfolio, because adding assets with low or negative return-correlations with the rest of the portfolio can stabilize portfolio income.

At the level of an individual commercial building, risk derives from the uncertainty of the rental prices it can command, the vacancies it experiences, and fluctuations in the operating costs it incurs. The variances in income and operating costs over time are measures of this risk. However, thinking of a building as a capital asset, a portfolio holder would want to convert the net income in each time period to a rate of return on the investment in the building, and change the variance in income and operating expenses into a variance of that rate of return. Taking the square root of the variance in the rate of return gives the standard deviation, and we have the two parameters used in modern capital asset pricing theory, the expected rate of return and its standard deviation.

The basic relationship in capital asset pricing is a positive relationship between the expected return on an asset and the risk associated with that return. To obtain a higher rate of return, one must incur more risk. Correspondingly, to get an investor to accept a higher risk, a higher expected rate of return must be offered. In terms of advanced buildings technologies, from the perspective of building owners rather than of technology developers, less thoroughly markettested technologies are riskier than better-known, standard technologies. While these 
technologies are characterized as offering higher rates of return, agents outside the development laboratory perceive that they also have higher risks.

The manager of any given building would like to make the net income from building as certain as possible, or at least as certain as is profitable. Some of the risk associated with the building is peculiar to the building, as a function of its location, its particular tenants' industries, the functional characteristics of the building, and the building's technical performance. Another component of the risk is just a function of doing business in the market-energy prices may spike, interest rate and exchange rate fluctuations may precipitate economy-wide changes in overall employment, and so on. A building owner can neutralize the first type of risk, called idiosyncratic, or nonsystematic, risk by diversifying his real estate holdings over a number of buildings. The systematic risk cannot be eliminated by diversification, either across a number of buildings or across entirely different types of assets, but an asset holder can trade some of that risk for a lower expected rate of return.

The fact that commercial buildings are traded in national capital markets, at least indirectly through real estate firms that own them, may influence the expense owners find it economical to put into individual buildings to reduce their income risk. The amounts and types of risks associated with commercial buildings derive from the market for space, but a price premium (the amount it is worth to pay to reduce risk in existing buildings) exists only for systematic risks, and that is determined in the national capital market together with risks in all other activities (Fisher 1992, 163). A real estate asset manager, thinking of purchasing an existing, or even a new, building, would take the national risk premium as given, make his or her assessment of the risk associated with the specific building, and bid a price accordingly. ${ }^{12}$ The price range undoubtedly would be developed from a cash-flow model summing discounted revenue and cost components over some time period, but the sum-total price would have to be converted to a rate of return and be compared with the minimum rate of return compatible with the assessed risk. The building would go to the highest price bidder, higher prices yielding lower rates of return. The capitalization of energy savings from advanced technologies would be subject to this sort of discipline from the national capital market.

In this way we can reconcile the behavior of the individual using cost/benefit analysis to select new, energy-efficient technologies for either a new or existing building, and the decisions made by a realty (or general) portfolio manager to get the highest rate of return from a portfolio subject to a certain risk or minimize the risk of a portfolio subject or getting at least a given rate of return. The former individual may be studying the net benefit of installing compact flourescent lighting in a large office building, with his eye on the implied rate of return. The latter decides how much to pay for the building, assuming it has come on the market for sale shortly after the lighting retrofit. The risk-return tradeoff made by the latter will determine the extent to which the energy savings of the new lighting system is capitalized into the transaction price of the building.

\footnotetext{
${ }^{12}$ This appears to characterize institutional bidding for office buildings: institutional portfolio managers, looking for safe assets, are willing to drive up the prices for office buildings with high proportions of long-term tenants, which offers close to a guaranteed income stream. Bidding up the price drives down the rate of return on the capital invested in the building to a level commensurate in a portfolio model with the lower risk of the fully occupied building (Graff and Webb 1997, 29).
} 


\section{OVERVIEW OF THE COMMERCIAL BUILDINGS INDUSTRY}

This section provides institutional details and descriptive statistics about the commercial buildings industry that the previous section has identified as having important implications for the deployment of new technologies. The first subsection introduces the agents who participate in this industry, the specific actions they take, and incentives they find. The second subsection addresses the financial risks in the industry and how agents deal with them. The final subsection identifies a number of empirical regularities in the industry that reflect the market outcomes of behavior relevant to DOE's goal of deploying advanced building technologies.

\subsection{The Actors and Institutions of the Commercial Buildings Industry}

The demand side of the industry is comprised of the owner and his agents (management and management service companies), the occupant (not necessarily the owner), and the lenders. The owner ultimately determines the physical characteristics present in a commercial building. Design teams design, and contractors build, what the client wants in terms of specifications and cost. In many cases, architects or contractors offer bids on a detailed building specification drawn up by an owner, and the building price will be fully determined before ground is ever broken. In a smaller percentage of cases, owners and designers work closely together to find a cost/specification combination that meets the owner's needs and capacities, but again the owner is the final arbiter of what goes into the building. The architectural and engineering disciplines contributing to the design phase identify the least-cost way of delivering the functional requirements specified by the owner. They can suggest particular choices of equipment and materials that may or may not represent a trade-off between higher first-cost and lower life-cycle cost, but the choice is strictly the owner's. ${ }^{13}$ A survey of 228 architects and engineers in California reports that owners have the most important role in energy-efficiency decisions in commercial buildings (Wright et al. 2000, 378). Reed et al. (2000) note that many owners have limited interest in cutting energy bills and limited willingness to use life-cycle cost investment criteria, but that they are interested in features that will make the activities conducted in their buildings more productive. ${ }^{14}$

\footnotetext{
${ }^{13}$ The lender's opinions cannot be ignored either. If the owner wants to build a more costly building than lenders want to finance, the owner always has the option of increasing his or her equity to let the loan plus equity cover the anticipated cost. So if an owner used a life-cycle cost evaluation to decide on specifications that yielded a higher first-cost and lenders were willing to offer financing only on a lower-first-cost set of specifications, the owner could make up the difference in cost with additional equity.

${ }^{14}$ The recent California experience with electricity and natural gas prices need not have significant long-run implications for the design of buildings, in that state or elsewhere in the country. The energy prices fell more quickly than was anticipated, through a combination of ordinary supply responses and the expiration of a number of unfavorable contracts. Consumption fell during the winter of 2001 without most consumers receiving price signals, primarily as an emergency response to rolling blackouts and the threat of worse consequences. As long as the expectation for energy prices in the future is for lower prices, and for fairly rapid return to lower prices after infrequent spikes, the incentive to prepare long-lived assets such as buildings for high prices will remain weak. Nonetheless, the electricity crisis in the state did prompt some energy-efficiency retrofits by some commercial real estate investment firms, as reported in several real estate trade magazines. Temporary electricity surcharges at hotels all across the country during the period, in regions not experiencing significant price increases and continuing considerably after the decline in prices, is better viewed as simple opportunism than the leading edge of heightened awareness of the value of energy efficiency.
} 
However, "the" owner of a commercial building is not necessarily straightforward. The initiator of a new building may be a developer. Shortly after completion of the building, the developer may sell the building in order to return to his or her principal business, bringing new buildings into existence, not owning and operating them. Commercial buildings are a component of the national capital market, with the ownership of many of them, especially the larger ones, being dispersed among institutional investors such as pension funds and insurance companies and realty management companies whose shares are sold on the stock exchanges. Such owners hold a portfolio of buildings, generally distributed over several categories of commercial buildings. When companies decide to build and own their own building space, they enter this space-andcapital market, possibly to earn a return on their building higher than they could obtain for the building in the open market. ${ }^{15}$ A company that owns its own space may not occupy all of that space but rent some, possibly much, of it out to other tenants, complicating the statistical reporting of owner-occupied buildings and floor space.

Firms that own and occupy their own space are equally governed by profitability and productivity concerns as are firms that pay monthly rent bills for floor space. If these owner/users occupied a structure that cost them more than it supplied them in productivity benefits, they would pay the bank more than the space is worth to them each month, whereas a renter in the same unfortunate situation would just pay the landlord more than the space was worth each month. There is no conceptual difference between the owner/user and renter on this account.

Management and management service companies operate and maintain buildings for owners, whether the owner itself is the occupant or the owner leases to tenants. Depending on contractual details, they have varying discretion and incentives to undertake upgrades of building components that could deploy advanced building materials (Lovejoy 1993; Whyman 1993; BOMA 2000a, 20-33; Reed et al. 2000, 276-280). Within the last decade, some of these management contracts have actually encouraged excessive operating costs, at least in the commercial apartment market, basing compensation on gross rental collections rather than on net operating income (Rosenberg and Corgel 1990).

The supply side is comprised of the architect, contractor, the various engineering disciplines and building trades, and the design team. The design team may be considered on the critical path for the deployment of advanced technologies in commercial buildings because it puts forth the first suggestions for equipment and material specifications. It supplies the physical details that implement the owner's specific functional demands regarding the buildings, responding either directly through consultation or indirectly through response to a request for proposals (RFP). The general contractor strives to build the design supplied by the design team, although this sequence of responses depends on the type of contract. An alternative contracting format, known as design/build, has been increasing its share of construction activity. In this arrangement, the design team, including the architect, is under the direction of the contractor. The

\footnotetext{
${ }^{15}$ This firm-specific "rent" could derive from internal configurations designed specifically for the firm's needs, as well as from a special locational configuration - access to a combination of other sites used frequently by the firm but not necessarily by other firms.
} 
motivation for the arrangement has been the hope that closer cooperation among the various disciplines would emerge and that construction time would be reduced.

In the construction phase, under any contract format, the general contractor has strong incentives to see that the specialized subcontractors build at least cost, since the general contractors typically are paid a fixed price by the owner, and if the construction costs them more that that, they eat the loss. Specialized contractors respond essentially passively to specifications supplied by the design team, as transmitted by the general contractor. Paid to implement the plans drawn up by the design team, these contractors have neither scope nor financial incentive to propose alternatives that would provide higher energy efficiency. Design and construction organizations focus on "getting in and getting out" quickly: responding quickly to requests for proposals, forming teams to get a job done, delivering a product on time, then walking away quickly. This project focus leads to information gaps between projects-duplicated efforts, missed opportunities, and failure to learn much from experiences (Ronco and Ronco 1996, 76).

Firms appear to have little incentive to compete with one another by offering newer technologies. The fee of the architect and general contractor may be either a percentage of total cost or a flat fee. Prices to subcontractors generally are firm-fixed prices. Once construction begins, general contractor and all subcontractors have strong incentive to minimize cost and construction time. The architect generally is responsible for overseeing construction and ordinarily has extensive authority to issue change-orders in response to cost overruns, frequently changing specifications on some equipment not yet installed without re-optimizing other components (some of which may already be installed) or otherwise allowing for operational interactions which can be important to the performance of advanced technologies.

Construction and A\&E firms vary greatly in size, just as do buildings themselves. While some of these firms have 10,000 or more employees, over 98 percent of both types of firm employ fewer than fifty employees. In fact, 68 percent of A\&E firms have one to nine employees, as do 83 percent of general building contractors. However, the large firms generate the bulk of the revenues: the largest 1.36 percent of general building contracting firms earn 40 percent of the revenue in that industry, while the largest 1.35 percent of A\&E firms take in 59 percent of the revenue in that activity. ${ }^{16}$ The larger construction and A\&E companies have the technical and financial capability to build larger and more complex commercial buildings. Although the large firms do enter the market for smaller buildings as well, the smaller companies are constrained to the smaller, simpler structures.

\subsection{Risks in Commercial Buildings}

Risk is a very prominent concern on both sides of the industry. On the supply side, the contract construction industry generates 6-8 percent of U.S. gross domestic product (GDP) and has about 8 percent of the total number of business firms in the United States, but experiences

\footnotetext{
${ }^{16}$ Department of Commerce, Economics and Statistics Administration, Bureau of the Census, 1992 Census of Construction Industries, 1992 Enterprise Statistics, Company Summary. Percentages calculated using Companies and Sales and Receipts data from Table 2, Company Statistics by Employment Size.
} 
around 12 percent of all business failures (Park and Chapin 1992, 36). Cost overruns as a consequence of poor cost estimation, unforeseen and uncontrollable delays, quality control problems, and delays of payments by owners and lenders are major contributors to these risks. Design and construction organizations face considerable unpredictability and unevenness in their work flow, which lets cash-flow problems emerge that quickly can lead to bankruptcy (Hillebrandt 1985, 80; Ronco and Ronco 1996, 76; Morton and Jaggar 1995, 148-150). The variability of contract formats available for construction allows many possible allocations of these risks between builders and owners but does not eliminate the risks (Morton and Jaggar 1995, 324330; Ritz 1996, Chapter 2). Rapid completion of construction is one of the primary means builders use to contain their business risk. To the extent that construction risk increases with length of construction period, large commercial construction projects probably contain more risk than small ones: in 1990-91, the peak rate of completion for projects under $\$ 250$ thousand was one month after start, while for projects above $\$ 10$ million, there were twin peaks at fifteen and eighteen months after start (Montgomery 1995, 157).

The risks on the demand side of the market tend to emerge after a building is constructed, although the bankruptcy of a construction firm during the building phase can drive up construction loan costs for the owner. Demand fluctuations, with attendant vacancies, are probably the greatest source of risk for building owners. For example, Hendershott et al. (1999, 378) report that the office vacancy rate in London of 2 percent in 1986 had risen to 18 percent in 1991. The best option that non-occupying owners have for insurance against these events lies in securing long-term leases prior to construction, and matching building functionality and qualityincluding productivity enhancements and energy efficiency as well as materials, workmanship, and design aesthetics) - to market demand. Even those options offer limited insurance when the firms who are their tenants experience cash-flow problems themselves because of regional demand disturbances or national or even international fluctuations of demand in their product markets. In developing the quality enhancements as self-insurance, however, an owner raises a building's cost and its rental rates, which can add to cash-flow squeezes on tenants. The fact remains though that there is some opportunity for building productivity features to act as revenue insurance for building owners.

Rate-of-return risk for individual commercial buildings tends to be high: an overall coefficient of variation (ratio of the standard deviation to the mean) of $2.8^{17}$ for transactions on retail buildings and 2.5 for transactions on office buildings. However, when allowing for the combination of individual buildings into portfolios of other buildings as well, the volatility of rates of return on entire building portfolios is much lower- from 0.29 to 0.54 (Webb et al. 1992, 351 Table 5). In the language of capital asset pricing, much of the risk of individual buildings is idiosyncratic risk and can be diversified simply through holding a larger number of buildings. The overall riskiness of commercial real estate as an asset class lies between the riskiness of stocks and bonds, although within this asset class, the risk-return combinations vary across the categories of retail, office, industrial, warehouses, and $\mathrm{R} \& \mathrm{D}$, office buildings generally offering the lowest returns and risks.

\footnotetext{
${ }^{17}$ The standard deviation of the rate of return is 2.8 times the mean rate of return.
} 


\subsection{Economic Activity in the Commercial Buildings Market}

The market context of commercial buildings is important in conditioning the decisions of agents on both the supply and demand sides of the market. Section 2.1 identified the different agents and roles in the commercial buildings market, and Section 3 relates how agents will behave in those roles under circumstances such as those that exist in this market. This subsection reports quantitative information on various aspects of the market outcomes that agents in the commercial buildings market are generating. It shows the types and volumes of activity and the relative magnitudes of different submarkets within the overall market, as well as some indicators of the state of energy-efficiency provision that the market has been delivering in recent years. For each of the subsections we discuss the implications of the market data for the task of accelerating the deployment of advanced buildings technologies in this sector.

\subsubsection{Size Distribution of New Commercial Buildings}

The vast majority of new commercial buildings recently constructed is in the two smallest size categories $\left(1 \mathrm{~K}-5 \mathrm{~K} \mathrm{ft}^{2}\right.$ and $\left.5 \mathrm{~K}-10 \mathrm{~K} \mathrm{ft}^{2}\right)$, as shown in Table 1 . However, each of the first six size categories has about the same percentage of new floor space, with the two largest size categories $\left(200 \mathrm{~K}-500 \mathrm{~K} \mathrm{ft}^{2}\right.$ and over $\left.500 \mathrm{~K} \mathrm{ft}^{2}\right)$ together capturing about the same percent of floor space as each of the smaller categories. The number of buildings declines precipitously as size category increases. The three middle size categories $\left(25 \mathrm{~K}-50 \mathrm{~K} \mathrm{ft}{ }^{2}, 50 \mathrm{~K}-100 \mathrm{~K} \mathrm{ft}^{2}\right.$, and $100 \mathrm{~K}-$ $200 \mathrm{~K} \mathrm{ft}^{2}$ ) account for almost 50 percent of new construction.

The smallest buildings tend to be built by the smaller contractors, operating on smaller profit margins and building for small firms with comparable margins; these offer fewer opportunities for "nonessentials." A large number of owners, allowing for chain owners of small buildings such as convenience stores, makes for a diffuse target for information. The largest two size categories of buildings contained 18 percent and 13 percent of new floor space in 1990-92 and 1993-95 in 0.7 percent and 0.5 percent of new buildings in those years, representing a more compact target of building owners. These buildings are constructed by the larger construction firms, which represent the innovative edge of the industry. When completed, these buildings are likely to house activities of larger corporate firms, which have both more financial flexibility to pay for productivity-enhancing features in buildings and greater need to distinguish themselves from competitors. One way of achieving such a corporate definition is to occupy more distinctive quarters. The larger buildings also are likely to become part of the commercial buildings component of regional or national investors' portfolios, which may have implications for how the rates of return on the individual buildings are treated. 
Table 1. New Construction and production input characteristics

\begin{tabular}{|c|c|c|c|c|c|c|c|c|c|c|}
\hline \multirow{3}{*}{$\begin{array}{r}\text { Bldg size }\left(\mathrm{ft}^{2}\right) \\
1,001-5,000\end{array}$} & \multicolumn{4}{|c|}{$\%$ of new floor space built in } & \multicolumn{4}{|c|}{$\%$ of new buildings built in } & \multicolumn{2}{|c|}{$\begin{array}{c}\text { Electricity consumption, } 19 \\
\text { all construction dates }\end{array}$} \\
\hline & \multicolumn{2}{|c|}{$1990-92$} & \multicolumn{2}{|c|}{$1993-95$} & \multicolumn{2}{|c|}{$1990-92$} & \multicolumn{2}{|c|}{ 1993-95 } & $\mathrm{kWh} / \mathrm{ft}^{2}$ & MWh/work \\
\hline & \multicolumn{2}{|c|}{12.2} & \multicolumn{2}{|c|}{15.7} & 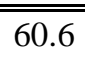 & \multirow{2}{*}{83.5} & 63.9 & \multirow{2}{*}{85.2} & $18.7^{1}$ & 10.6 \\
\hline $5,001-10,000$ & \multicolumn{2}{|c|}{14.2} & \multicolumn{2}{|c|}{14.4} & 22.9 & & 21.3 & & $9.9^{2}$ & 9.2 \\
\hline $10,001-25,000$ & \multicolumn{2}{|c|}{9.7} & \multicolumn{2}{|c|}{8.9} & \multicolumn{2}{|c|}{7.3} & \multicolumn{2}{|c|}{6.4} & 10.0 & 8.7 \\
\hline $25,001-50,000$ & 14.6 & \multirow{3}{*}{46.1} & 16.9 & \multirow{3}{*}{48.1} & \multicolumn{2}{|c|}{5.0} & \multicolumn{2}{|c|}{4.5} & 12.1 & 9.1 \\
\hline $50,001-100,000$ & 15.8 & & 19.8 & & & & & & $13.5^{2}$ & 11.0 \\
\hline $100,001-200,000$ & 15.7 & & 11.4 & & & & & & 15.0 & 11.7 \\
\hline $200,001-500,000$ & \multicolumn{2}{|c|}{8.1} & \multicolumn{2}{|c|}{6.7} & \multicolumn{2}{|c|}{0.5} & \multicolumn{2}{|c|}{0.2} & 16.2 & $11.9^{3}$ \\
\hline over 500,000 & \multicolumn{2}{|c|}{9.7} & \multicolumn{2}{|c|}{6.2} & \multicolumn{2}{|c|}{0.2} & \multicolumn{2}{|c|}{0.1} & $16.3^{1}$ & $8.6^{3}$ \\
\hline \multirow[t]{2}{*}{ TOTAL } & \multicolumn{4}{|c|}{ total new floor space $\left(10^{6} \mathrm{ft}^{2}\right)$} & \multicolumn{4}{|c|}{ total \# new buildings } & \multicolumn{2}{|c|}{ all bldgs, all construction dat } \\
\hline & \multicolumn{2}{|c|}{2,590} & \multicolumn{2}{|c|}{2,059} & \multicolumn{2}{|c|}{218,000} & \multicolumn{2}{|c|}{202,000} & 13.4 & 10.0 \\
\hline
\end{tabular}

${ }^{1}$ Difference in $\mathrm{kWh} / \mathrm{ft}^{2}$ between buildings in the smallest and largest size categories is not statistically significant at 5\%. ${ }^{2}$ Difference in $\mathrm{kWh} / \mathrm{ft}^{2}$ between buildings in the 5,001-10,000 $\mathrm{ft}^{2}$ and 50,001-100,000 $\mathrm{ft}^{2}$ size categories is statistically different at $5 \% .{ }^{3}$ Difference in MWh/worker between buildings in the two largest size categories is not statistically significant at 5\%; since all other values of $\mathrm{MWh} /$ worker are between these values, none of them are statistically different, across all size categories.

Source: 1992 Commercial Buildings Energy Consumption Survey (CBECS), 1995 CBECS. 


\subsubsection{Electricity Use and Energy Efficiency Measures in New Buildings}

Some aggregate evidence suggests that contractors of substantially different size and sophistication are delivering roughly the same energy-efficiency characteristics in the new buildings they construct. Recalling that larger firms build the larger buildings and the smaller firms build the small buildings, differences between electricity use per square foot and per worker are not statistically different between the smallest size new construction and the largest, as shown in Table 2. While some activities have substantially higher energy use per square foot of building floor space than do most others (food sales, food service, and health care), when all building types are aggregated, larger buildings do not appear to be achieving (or to have achieved) greater efficiencies in energy use; larger contracting firms are not delivering higher energy efficiency than are small builders. Further disaggregation of buildings by both function and size might reveal evidence of some distinction in the delivery of energy efficiency, but the scope for differences would not appear to be large.

However, evidence on materials and technology used in new buildings does show some variability in deployment of some technologies by building size. According to data assembled by NIST (Chapman and Rennison 1998, pp. 174-178, Tables 6.50-6.58), some important building shell energy efficient features (roof, ceiling and wall insulation) in new commercial construction do not increase in frequency (percent of floor space) in larger buildings. Tinted reflective or shading glass and exterior or interior shading or awnings do increase with building size. Building HVAC energy-efficiency measures in new construction also increase in frequency with larger size buildings, as do many energyefficient lighting features.

\section{Table 2. Electricity consumption, by building activity}

\begin{tabular}{|l|c|c|}
\hline Building use & $\mathrm{kWh} / \mathrm{ft}^{2}$ & MWh/worker \\
\hline \hline Education & 8.4 & 6.4 \\
\hline Food sales & 54.1 & 53.3 \\
\hline Food service & 36.0 & 20.8 \\
\hline Health care & 26.5 & 13.8 \\
\hline Lodging & 15.2 & 20.1 \\
\hline Mercantile \& services & $11.8^{1}$ & $11.1^{2}$ \\
\hline Office & $18.9^{1}$ & $7.3^{2}$ \\
\hline Public Assembly & 12.7 & 16.7 \\
\hline All private, owner-occupied & 13.4 & 10.1 \\
\hline All private, non-owner-occupied & 12.4 & 8.8 \\
\hline All bldgs built 1980-89 & 15.9 & $9.4^{3}$ \\
\hline All bldgs built 1990-92 & 18.8 & $12.3^{3}$ \\
\hline All bldgs built 1993-95 & 17.5 & $16.8^{3}$ \\
\hline
\end{tabular}

${ }^{1}$ Significantly different at 5\%. ${ }^{2}$ Significantly different at $5 \% .{ }^{3}$ Difference not statistically significant at $5 \%$.

Source: 1995 CBECS.

\subsubsection{Ownership of New Construction}


According to the Commercial Buildings Energy Consumption Survey (CBECS), in 1995, 82 percent of privately owned, occupied buildings in the United States, and 65 percent of the floor space, were buildings in which owners occupied some of the space (Table 3). In 1993, 80 percent of privately owned new buildings, and 77 percent of new floor space, were in buildings similarly used by owners (CBECS, respective years, Table A $10)$. The $C B E C S$ definition of "owner occupation" does not imply that building owners were using all of this floor space themselves, or even a large proportion of it. In the 199092 period, construction in office and in mercantile and service activities represent nearly half of new floor space. ${ }^{18}$

Owner-occupied buildings can be tailored more specifically to the needs of a known user than can speculative buildings. Correspondingly, productivity-enhancing building features should be more easily marketable to known owners of new buildings. However, the extensiveness of the "split-incentive" problem commonly associated with speculative buildings cannot be determined from the CBECS data on ownership status. The prominence of commercial buildings in the national capital market portfolio suggests that the ownership of new and existing floor space should be examined further.

\section{Table 3. New construction, owner occupation}

\begin{tabular}{|l|c|c|c|c|}
\hline \multirow{2}{*}{ Building use } & \multicolumn{2}{|c|}{ \% of new floor space } & \multicolumn{2}{c|}{ \% of new bldgs } \\
\cline { 2 - 5 } & $1990-92$ & $1993-95$ & $1990-92$ & $1993-95$ \\
\hline \hline $\begin{array}{l}\text { All private, owner-occupied } \\
\text { buildings }\end{array}$ & $77^{1}$ & $65^{1}$ & 82 & 84 \\
\hline Education & 9.2 & 14 & 7.8 & 6.4 \\
\hline Mercantile \& services & 24 & 22 & 22 & 24 \\
\hline Offices & $22^{2}$ & $11^{2}$ & $17^{3}$ & $11^{3}$ \\
\hline Warehouses \& storage & 12 & 20 & 17 & 35 \\
\hline
\end{tabular}

${ }^{1}$ The difference between $77 \%$ in $1990-92$ us not statistically significant from the value of $65 \%$ in 1993 95, at 5\%. ${ }^{2}$ The difference between $22 \%$ in $1990-92$ and $11 \%$ in $1993-95$ is statistically significant at $5 \%{ }^{3}$ The difference between $17 \%$ in $1990-92$ and $11 \%$ in $1993-95$ is not statistically significant at $5 \%$. Source: 1992 CBECS, 1995 CBECS.

\subsubsection{Component Cost Structure of Commercial Buildings}

The dominant cost share of commercial buildings is for the structural component, which accounts for around 75 percent of commercial building cost (Table 4). ${ }^{19}$ HVAC

\footnotetext{
${ }^{18}$ Lagging office construction in 1993-95 reflects the continuing effect of the 1986-92 office market recession, although the bottom dropped out of that market in late 1989, and by mid-1993, starts were about one-third of their rate in late 1989 (Mills 1995). Office construction had not quite regained its 1989 level in terms of constant-dollar expenditures by 2000 (U.S. Census Bureau, Historical Value of Construction Put in Place, http://www.census.gov/ftp/pub/const/C30/c30_hist.html).

${ }^{19}$ The category "structural system" includes roofs and wall cladding, but the data available do not let us separate these components.
} 
systems account for around 13.5 percent of office building cost and electrical systems for 8.4 percent. For supermarkets and grocery stores, the structural component is essentially the same as for office buildings, but the relative cost shares of HVAC and electrical systems are reversed.

Larger cost shares offer larger opportunities for cost cutting, so owners, as well as design teams and builders, will anticipate easier payback from looking more closely at structural systems as prime areas for cutting costs. Additionally, percentage cost increases in systems with small cost shares, such as HVAC and electrical, will contribute less to overall building costs. Consequently there could be greater opportunity for substituting higher-first-cost equipment and materials in HVAC and lighting systems than in structural systems. Conversely, savings in first-costs available in the HVAC and electrical systems of new buildings will not be as important to owners or builders as comparable percentages of savings in other components which claim larger cost shares.

Table 4. Component cost shares in commercial buildings, 1986 (in percents)

\begin{tabular}{|l|c|c|c|}
\hline Building type & $\begin{array}{c}\text { Structural/envelope } \\
\text { component }\end{array}$ & HVAC component & Electrical component \\
\hline office buildings & 74.9 & 8.7 & 13.1 \\
\hline $\begin{array}{l}\text { supermarkets \& } \\
\text { grocery stores }\end{array}$ & 74.9 & 13.5 & 8.4 \\
\hline
\end{tabular}

Source: 1987 Dodge Square Foot Cost Data. Princeton: McGraw-Hill, 1987, sections F and $\mathrm{G}$.

\subsubsection{Energy Use in Office Buildings}

Energy costs tend to be small fractions of total business expenses for most firms, particularly those using commercial, nonmanufacturing buildings. The energy cost share of running commercial buildings is correspondingly low-an average of 4.6 percent of expenses per square foot for all office buildings in the United States in 1999 (BOMA $2000 \mathrm{~b}, 25) .^{20}$

Since even a large fraction of a small fraction is a small fraction, energy savings opportunities need not look particularly exciting to firms with more consequential decisions to make. Since most firms are constrained in the capital market (borrowing costs increase as a firm borrows more money), and any investment will be compared with other investment opportunities, attention to energy-saving opportunities should be predicted to be limited, which they are.

\subsubsection{The Relative Magnitudes of the New Construction and Retrofit Markets}

\footnotetext{
${ }^{20}$ Some writers report energy costs as a percent of operating expenses rather than of total user costs facing renters and owners, which is considerably higher-in the range of 25-30 percent. Operating expenses exclude mortgage payments and related costs, which both owners and renters must pay for office space.
} 
The new construction market appears to be the larger target for the deployment of new buildings technologies, as the following calculations suggest. Between 1992 and 1996, roughly 60 percent of commercial-institutional construction activity (in dollars) was in new construction, roughly 10 percent in maintenance, and roughly 30 percent in alterations (retrofits), as shown in Table 5.

Since new construction includes a large proportion of structural work that need not occur in alterations, it is possible that larger cost shares could go to the component systems where energy-efficiency technology can make contributions. The buildings retrofit market has commonly been identified as large relative to the new construction market since new construction adds only around 5 percent to the existing building stock in any particular year. In fact, as Table 6 shows, the cost shares of these components in retrofit activity are not much different from their magnitudes in new construction. The share of HVAC costs in alterations is smaller than in new construction: in 1997, 5.3 percent in hotels, 4.6 percent in office buildings, 4.3 percent in other commercial buildings (stores and restaurants primarily); 6.8 percent in educational buildings; and 7.6 percent in hospitals and institutional buildings. Electrical shares in retrofit costs are substantially larger: an average of 15 percent of total costs, compared to 5.5 percent for HVAC, roughly their share in new construction of office buildings. Building envelope and fenestration (glass and glazing) retrofit cost shares are quite low.

New construction may well be the largest target for securing the market penetration of energy-efficient/productivity-enhancing equipment and materials and systems integration. The fact that annual new construction usually amounts to only around 5 percent of the existing building stock does not automatically imply that the retrofits market for energy-efficiency technologies is larger than the new construction market. More activity occurs in new construction than in retrofits and the cost shares of components are roughly the same in both. Furthermore, new construction permits a larger degree of critical systems integration which could enhance building productivity.

Table 5. Shares of value in construction, $1992-1996$ (in percents)

\begin{tabular}{|c|c|c|c|}
\hline Year & New construction & Maintenance \& repairs & Alterations (retrofits) \\
\hline 1992 & 57.0 & 11.6 & 31.4 \\
\hline 1993 & 57.3 & 11.5 & 31.2 \\
\hline 1994 & 56.6 & 11.6 & 31.7 \\
\hline 1995 & 58.3 & 11.2 & 30.5 \\
\hline 1996 & 59.3 & 10.9 & 29.8 \\
\hline
\end{tabular}

Source: Robert E. Chapman and Roderick Rennison, An Approach for Measuring Reductions in Operations, Maintenance, and Energy Costs: Baseline Measures of Construction Industry Practices for the National Construction Goals. NISTIR 6185. Gaithersburg, Md.: National Institute of Standards and Technology, July 1998, p. 34, Table 3.4, Part A.

Table 6. Shares of component systems in total value of additions, alterations, or reconstruction, 1997 (in percents) 


\begin{tabular}{|l|c|c|c|c|}
\hline Building type & HVAC & Electrical & $\begin{array}{c}\text { Building } \\
\text { envelope }\end{array}$ & Fenestration \\
\hline All types & 5.5 & 15 & 0.9 & 0.7 \\
\hline hotels & 5.3 & 10.2 & 0.1 & 1.2 \\
\hline office bldg & 4.6 & 18.3 & 1.3 & 0.7 \\
\hline office n.e.c. & 4.3 & 13.8 & 0.9 & 0.7 \\
\hline education & 6.8 & 12.5 & 0.6 & 0.7 \\
\hline health & 7.6 & 13.7 & 0.7 & 0.5 \\
\hline
\end{tabular}

Source: 1997 Economic Census, Construction Industry Series. Tables 7 and 9. "Value of Construction Work...by Type of Construction: 1997" and "Dollar Value of Business ...by Kind of Business Activity: 1997."

\subsubsection{What Owners Want Compared to What They Have}

Owners are interested in features of buildings that they believe will enhance the productivity of their principal business, but tend to be less interested in energy efficiency per se unless energy costs are a large share of their total business costs. For example, the Building Owners and Managers Association (BOMA) 1999 Office Tenant Survey found that 99 percent of their sample of office tenants cited comfortable temperature, indoor air quality, and acoustics/noise control as important, while only 89 percent-admittedly, still a large percent — considered cost of after-hours heating/cooling important. A smaller proportion of these respondents reported themselves to be satisfied with the current status of the space quality indicators than reported satisfaction with their energy consumptionfrom 74 to 83 percent for the space quality compared to 79 percent for the energy efficiency. It is also noteworthy that whereas 90 percent of these respondents considered environmentally friendly building systems and materials to be important, 98 percent were satisfied with their current situation on that score (BOMA International and ULI-the Urban Land Institute, 1999, Figure 3.1, p. 19). Thus more office tenants appear to consider what could be called productivity characteristics of space to be important than deem energy-efficiency and environmental characteristics important, but more tenants are satisfied with what they have in the way of energy and environmental characteristics than with their productivity characteristics.

The same preferences undoubtedly will apply to remodeling (retrofitting) of existing buildings. Investment calculations for retrofitting will include any costs of foregone production during the construction period as well as direct equipment, materials, and installation costs.

\section{THE ENERGY-EFFICIENCY GAP IN COMMERCIAL BUILDINGS AND POLICY INTERVENTION}


The term "energy-efficiency gap" refers to the widely reported discrepancy between the profitability of available energy technologies for buildings and the actual deployment of these technologies in suitable applications. A considerable literature documents these "inefficiencies," but more central to the present analysis is the literature that struggles to understand why these gaps remain so persistent and, correspondingly, considers policies that could reduce the gap by facilitating the adoption of the newer technologies. ${ }^{21}$ Subsection 4.1 reviews explanations in the literature for the persistence of the gap and its recommendations for accelerating deployment of energy-efficient technologies. Subsection 4.2 discusses the purposes of intervention and reports on current policy strategies aimed at commercial buildings.

\subsection{Accounting for the Gap}

In the analysis of the energy-efficiency gap, the retrofit market has attracted more attention than new commercial construction, possibly because of the perceived magnitude of retrofit opportunities for new technologies. These studies have revealed much about the decision-making processes and criteria of building owners and users and other agents participating in this market, but less on those agents' goals and on the position of buildings and space in their overall business strategies.

In one of the earlier studies in this body of literature, Koomey (1990) characterized the reasons for non-adoption of energy-efficient technologies in new commercial buildings as market failures of one or another type: imperfect competition, information costs and asymmetries, split incentives, cash-flow constraints, and varieties of non-rationality among economic agents, among others. Since most types of market failure have relatively standard, recommended remedies, he was able to identify a number of policies for encouraging the use of the higher-efficiency equipment, ranging from minimum efficiency standards to a number of information provision programs, focused primarily on the energy-saving characteristics of the technologies, and aimed principally, but not exclusively, at designers and architects. Recognizing that the financial incentives reside with the developer, he suggested that developers be targeted for rebate offers for individual technology adoptions. His evidence for market failure of one sort or another, although pinpointing precise accounting for individual failures, was low deployment rates of a number of individual technologies whose rates of return were estimated to be substantially higher than market rates of return.

Several studies have focused on commercial building retrofits from the perspective of corporate building owners: Cebon (1992), DeCanio (1993), DeCanio and Watkins (1998), and Kulakowski (1999). DeCanio (1993) was the first to point, at a conceptual level, to the differences between firms and individuals in terms of how they acquire and process information. While individuals have limited resources to gather information and make calculations of the best course of action, all their incentives are weighed up in a

\footnotetext{
${ }^{21}$ E.g., Koomey and Sanstad 1990; Lovins and Lovins 1991; National Academy of Sciences 1992; Koomey et al. 1996; DeCanio 1998; Brown 2001.
} 
single scale, so to speak. Firms typically have more resources to gather and process information, but as collections of separate departments, not all the goals and incentives are completely aligned across departments. Additionally, there are real costs of transferring appropriate information across departmental boundaries at the critical times, so generally no department knows everything that all the other departments know, which sometimes includes some items that they would benefit from knowing. One implication for corporate adoption of energy-efficient technologies in building retrofit opportunities is that insufficient information distribution through the organization, divergent incentives, or both, are quite likely to keep firms from choosing the economical optimal (profitmaximizing) level of energy efficiency. Another is that firms have limited resources, just as do individuals, even if their limits are larger, and consequently focus those resources on what they consider to be their most important goals - the "core business." Decisions closer to the core business get more attention, and decisions perceived to be further from the core decisions tend to be made with rules of thumb that may not fully maximize possible profits. The cost of supplying the additional resources to fully maximize the potential profits from the non-core opportunity may be taking them away from other departments that make more far-reaching decisions in the core business area. The firm may never know whether its impressionistic guess about the overall profitability of moving some of its analytical resources around among departments is correct or not. The cost of finding out could just about eat up any profit differential available from the rearrangement. Many firms would be unwilling to spend the resources to find out.

Cebon (1992) and Kulakowski (1999) each conducted interview-based studies of two actual corporate organizations and their findings show the real-life details of how DeCanio's theoretical findings work in practice. Cebon studied two universities and found that facilities departments, who are responsible for energy-efficiency investments, although they were organized differently, had interactions with other departments that affected their ability to study and implement profitable energy-efficiency investments. Kulakowski studied one large university and one moderately large private corporation and uncovered other details. The magnitude of the potential investment determined which department (facilities or capital budgeting) had the authority to make the investment decision, and the location of that decision authority determined the other investments with which energy efficiency in the physical plant competed. Additionally, facilities department personnel tended to use simplistic rules of thumb in analyzing profitability, and not infrequently misused those. Furthermore, the attractiveness of the presentation of investment recommendations to higher authority affected those recommendations' receptions. The devil—or at least one of them-clearly is in the details, and the simple application of investment theory is misleading when applied to discrete-sized, real investments of modest magnitude undertaken by large firms.

DeCanio and Watkins (1998) conduct an empirical examination of whether the investment decision criteria firms use depend on some firm characteristics, primarily financial. They pick participation in EPA's Green Lights program as a surrogate for a standard investment decision criterion and contend that characteristics of firms should not affect that criterion if the simplistic textbook version of the corporate investment decision 
is correct. Quite expectedly, many firm characteristics do affect participation in the Green Lights program, but the interpretation of this statistical finding is not completely unambiguous. One reasonable interpretation conforms with DeCanio's (1993) paper, which implies that the return on investment required by firms may differ in a complex manner according to its internal organizational characteristics. This interpretation of the finding is consistent with the evidence on the internal organization of energy-efficiency investments reported by Cebon and Kulakowski.

While these studies deal with agents on the demand side of the buildings industry, in focusing on the energy efficiency characteristics of the investments, they sidestep the issue of what the demanders of buildings actually have demands for. Firms that use offices have demands for comfort - temperature and humidity-illumination, and productivity of their employees. While fresher air circulating through a building will keep employees more alert and healthier, thus enhancing their productivity, firms are likely to focus on the effect on their workers' productivity rather than on either the cubic feet per second of air flow or the energy efficiency of the HVAC system that delivers it. Thus, these studies are focusing on supply-side aspects of these technologies rather than on the aspects of them that building occupants actually notice and want.

\subsection{Policy Interventions in the Commercial Buildings Market}

The current policy interventions in commercial buildings appear to rely primarily on informational explanations of the energy-efficiency gap. Public R\&D is a solution to public-good information problems, and the market transformation programs emphasize information provision to prime the market for new technologies. It is not clear that a major effort has been made to implement policies based on the irrationality explanations of the gap.

DOE's R\&D on energy-efficient buildings technology is a major policy intervention in an area where private firms find limited incentive to conduct technological R\&D themselves. While this policy direction changes the menu of options from which consumers can choose, it does not directly alter the choices they would make. Consequently, a number of federal and state agencies, and some private firms and nonprofits have developed a variety of programs - the market transformation programsto nudge demands toward more energy-efficient varieties of building equipment.

The market transformation revolution in the energy conservation movement has emphasized a combination of information provision, temporary subsidies, and standards to permanently change the demand for various energy-efficient varieties of a number of goods. DOE's Rebuild America Program, the Environmental Protection Agency's (EPA's) Green Lights Program, and the DOE/EPA Energy Star Buildings Program all aim market transformation efforts at commercial buildings, the former with the full array of energy-efficient building technologies, the latter focused on efficient lighting. Other market transformation programs, many sponsored by utilities, also target commercial buildings. These programs primarily provide information about higher-efficiency 
technology alternatives and aim more at the retrofit market than new construction.

Temporary subsidies (often in the form of rebates) may be a way to provide market experience, and the accompanying performance information so critical to new technologies. Both tools can help consumers locate the values they are looking for within a market context, and they may be able to shift up the demand for some of these products and techniques. Nonetheless, these programs still emphasize reductions in relatively small cost shares that generally are outside the principal business lines of the firms addressed by the programs.

\section{FINDINGS AND POLICY/RESEARCH DIRECTIONS}

This report has provided a brief review of the market for advanced energy-related technologies and systems integration in commercial buildings from a business perspective. Our purpose in doing this is to add institutional context to a body of literature that has consistently found an energy-efficiency gap. This gap suggests a failure by the buildings sector to take full advantage of cost effective technologies, in essence ignoring opportunities for profit.

Our review suggests that there are many reasons why the energy-efficiency gap finding may exist. Most of these are structural and occur as a result of the specific manner in which the commercial buildings industry does business. However, gaps in important information and knowledge of the industry remain. The findings we report below may be considered suggestions or hypotheses to be examined more fully in subsequent enquiry. Nevertheless, they provide a starting point for marketed oriented research, coordinated with ongoing BTS road mapping efforts, that would seek behavioral explanations for market outcomes that the literature to date often has been quick to dismiss as flawed.

We believe that this type of enquiry is separate from the study of whether or not government intervention in buildings energy technology markets is warranted. More to the point, if government seeks to exercise its prerogative to promote energy efficiency - a practice that could be supported by a variety goals - it should do so armed with the best possible understanding of the markets it wishes to influence.

\subsection{Principal Structural Findings}

For all practical purposes, the market for energy-saving technologies is a demand driven market. This means that to find market acceptance, buildings buyers, owners, and occupants must have a willingness to pay for these technologies, which are in many cases (but not all) more expensive than alternative, less efficient technologies. ${ }^{22}$

\footnotetext{
${ }^{22}$ Some of the costs of the newer technologies include builders' costs of learning how to work with the new systems, so the simple purchase cost need not give a complete picture of the cost of using them.
} 
The supply side of the buildings industry possesses very few situations in which agents have independent incentive to use new technologies embodying higher energy efficiency. However, almost paradoxically, it is the supply side through which these technologies find their way into the market. Thus one is faced with a situation in which buyers, who are focused on profits, not building technology, must be willing to pay for technologies produced by suppliers, who understand the technologies, but have little or no influence over their use.

The energy-efficiency gap literature sometimes suggests that building buyers employ unreasonably high discount rates for energy saving technologies, are short sighted in their failure to employ life-cycle costing, and are myopically focused on first costs of building construction. Most of these findings are likely accurate, but are in fact "residual findings" that drop out of studies focused on the implications of energy technology choices rather than on the actual study of building markets. If similar scrutiny were given to, say, elevator technology, it might be found that buyers, owners, and occupants are equally lax in implementing cutting edge technologies. This is simply to say that because energy is an element of high importance in the nation's policy agenda and has been studied extensively, that we are particularly sensitized to its use.

This report focuses largely on the incentives faced by building owners. These incentives are reviewed by lenders and enforced by the terms through which lending agreements - for both construction and ownership loans - are put into place. When building technologies have higher first-costs than conventional equipment, either directly or by having higher installation costs, buyers have diminished incentives to require them. Under any circumstances general and special contractors have little or no incentive to promote their use, and design teams have incentive to use them only in circumstances where the building cost is still a negotiable item. Builders are more responsive to technical innovations that would reduce construction cost and time of a given building than they are to innovations that change the array of services delivered by buildings without definite signals from clients (owners) that they want them.

\subsection{Energy Efficiency and Building Productivity: Opportunities and Needs}

Setting aside for a moment DOE's current activities to promote energy technology use, there are a number of steps that could be taken that would better equip DOE to implement new or improved policy. These involve gathering new information on the full extent of benefits that new energy-efficient technologies might confer, gaining a better understanding of the decision process the demand side uses in evaluating buildings as capital investments, and reconsidering policy implementation to take advantage of these new insights.

In general, the decision making process used by demanders of buildings centers on perceptions of value and on risk management. Presently, there is little solid information available on the productivity effects of many energy-efficient building technologies, in the 
terms in which building owners and tenants think of productivity. Builders have no incentive to develop that information, and it is generally too expensive, and has too much of a public-good quality, ${ }^{23}$ for individual building users to develop for themselves. Some scattered research has been funded by utilities (e.g., Reed et al. 2000), but its details remain largely proprietary. This is an under-researched topic of considerable importance to energy efficiency and is a proper subject for government $R \& D$, possibly in conjunction with trade associations such as the Building Owners and Managers Association (BOMA) and the International Facilities Management Association. Detailed recommendations for how to analyze these demands for features of commercial buildings comprise the topic of the third report of the project, but at a general level, those studies should focus on how well the commercial buildings market is capitalizing the productivity value capable of being conferred by advanced building technologies.

Regarding risk management, there is little research that studies the concerns of buyers over uncertainty associated with new technologies. It is almost axiomatic that the uncertainty associated with a new technology would center on that technology's performance, yet studies of these technologies' deployment appears to center on peripheral influences, such as energy prices. We examine this topic more thoroughly in a forthcoming report, but in general solving these problems would require, first, an adequate understanding of the relevant behavior and, second, a modification of policies to take this into account.

It will be difficult to reduce the importance of first cost of new technologies, even if decision makers were to adopt life-cycle cost evaluations, because the investments incur interest charges on the first cost over the life of the loan. Consequently, it may repay DOE to focus R\&D on reducing the cost of these new technologies without sacrificing their desired technical properties. Adding multifunctionality to new technologies, if that could be done without raising the cost of the products, could offer additional benefit streams beyond energy savings for the same interest cost.

Finally, there is an overall need to coordinate policy with behavior, and this is a task for the next phase of research. Simple examples include providing buyers with digestible information about how new technologies affect building productivity. Like the scholar whose technical papers drag the reader through the same difficult process of discovery that the scholar endured, the literature on energy technologies seems to suggest that building owners should personally examine each building component, from blueprints upward, to assure themselves that the building is optimized. To do so would be to present the buyers with analysis of minuscule cost components. Might it not be better to present an optimized building energy system of sufficient scope and scale to capture the attention of an entrepreneur whose interest is in profits rather than energy?

\footnotetext{
${ }^{23}$ Which means that, whoever pays for it, everybody gets the benefit of it, so no individual has any incentive to pay for it, leaving it a task for the public sector.
} 
In sum, the present findings argue that the energy-efficiency gap might well be interpreted as a motive for exploring buildings institutions with sufficient scrutiny to identify policy-relevant points of entry and explore the logical implications of these points for policy. The technology road-mapping process provides the logical vehicle for such an enquiry.

DOE should augment its targeting of information at supply-side participants with comparable targeting of demand-side participants - building owners and users-with information about features they want. For example, more attractive office space is an important offering when workers occupy those quarters eight to twelve hours a day or longer. Energy-efficient technologies that enhance livability of a building should be marketed to such demanders on the basis of the latter characteristics in addition to, if not in place of, energy efficiency. However, successful marketing depends on the availability of reliable information targeted to what buyers in the market want. 


\section{APPENDIX. Capitalization of Energy Savings}

We use an approximation to a cash-flow valuation model to study the effect of installing an advanced building technology instead of a standard version. It is an approximation because we do not determine full net present values. As an alternative we lay out the income and expenses of an office building, on a per square foot basis for a single period, which we can assume to be the first year of operation: gross income, less O\&M expenditures, fixed expenses, and debt service payments equals the building owner's residual income. The NPV of the building could be calculated by multiplying each of the income and expense components by a common annuity factor which would discount future values over the life of the mortgage and sum them to a present-value equivalent. The annuity (discount) factor is unaffected by changes in the energy components of the balance sheet, although of course the NPV of those changes will be increased by the same percentage as the change in the first period, assuming for simplicity no change in effectiveness of the measures over time.

Table A.1 reports the income and expenses of an office building, based on 1999 data from BOMA (2000, p. 25). The $\$ 22 / \mathrm{ft}^{2}$ gross income is an asking rental times the occupancy rate (one minus the vacancy rate). The difference between total income and the sum of fixed and operating expenses is comprised of debt service payments and residual income (profit) to the owner. We used the ratio of debt service to net operating income (gross income minus O\&M costs) to estimate the debt service payment, which leaves the residual payment to the owner as an endogenous variable of sorts, to be determined by the arithmetic of changing costs and incomes. The $\$ 3.95 / \mathrm{ft}^{2}$ residual income represents just under an 18 percent rate of return on the owner's investment in the building.

The first column of this table reports the income-expense balance for a standard HVAC system. The second and third columns suppose that an advanced HVAC might be installed in this building instead, at 30 percent and 10 percent incremental costs respectively. Dodge data reports an average of 8.7 percent of building first-costs going to HVAC systems in new office buildings. The second column assumes that the trade-off between first-cost and annual energy savings involves a 30 percent increase in the cost of the HVAC system to obtain a 33 percent reduction in HVAC energy costs each year of the building's lifetime (assumed implicitly to be the length of the mortgage, although we need not define that lifespan). Thus 8.7 percent of the building's first-cost is increased by 30 percent, for an overall 2.61 percent increase in the building first-cost. We translate this into a 2.61 percent increment in the debt service payment in column 2 of Table A1, alongside a reduction in the HVAC energy cost from $\$ 0.65 / \mathrm{ft}^{2}$ to $\$ 0.43 / \mathrm{ft}^{2}$.

Doing the arithmetic in column 2, we find an increase in net operating income to $\$ 12.52 / \mathrm{ft}^{2}$ from $\$ 12.30 / \mathrm{ft}^{2}$, which is paralleled by an increase in the debt service payment to $\$ 8.57 / \mathrm{ft}^{2}$ from $\$ 8.35 / \mathrm{ft}^{2}$. Entirely fortuitously, these changes in revenues and expenses leave the owner's residual income exactly unchanged, which means that the incremental value of the energy savings from advanced building equipment, including the incremental 
debt service on the equipment, is capitalized at zero dollars per square foot. ${ }^{24}$ An owner would be indifferent between the advanced HVAC equipment and the standard equipment when faced with these numbers. If the HVAC cost share were smaller, the capitalized value of the advanced equipment would be positive, whether the rate of return were high or low. Similarly, if the incremental cost of the advanced equipment were less than 30 percent more than the standard equipment, or if the energy savings were greater than 33 percent, the capitalization would be positive. If we reversed those hypothetical parameter changes from our current values, the capitalization would be negative.

In column 3, gaining the electricity cost reduction for a ten percent incremental cost for the HVAC system yields an increase in the building owner's residual income of 3.79 percent, raising it to $\$ 4.10 / \mathrm{ft}^{2}$ from $\$ 3.95 / \mathrm{ft}^{2}$. While the capitalized value of the gross savings in the utility bill per square foot is $\$ 1.09$, it must be remembered that the owner is paying interest on the incremental cost of the HVAC system that delivers this saving, and the net capitalized value of this energy-bill saving is 13.8 percent of the gross capitalized value. Taking into account paying for the saving whittles away its financial significance substantially.

\footnotetext{
${ }^{24}$ Koomey (1990, Chapter 6) used a cash-flow program to calculate net present values of a hypothetical building under alternative equipment specifications, but he appears to have assumed a capitalization rate rather than deducing it from the data he entered.
} 
Table A1. Cash-flow analysis of alternative equipment specifications

\begin{tabular}{|c|l|l|l|}
\hline Cash flow components & \multicolumn{1}{|c|}{$\begin{array}{c}2 . \\
\text { Base case }\end{array}$} & $\begin{array}{c}\text { Advanced HVAC } \\
\text { system (30\% } \\
\text { incremental cost) }\end{array}$ & $\begin{array}{c}\text { Advanced HVAC } \\
\text { system (10\% } \\
\text { incremental cost) }\end{array}$ \\
\hline Total income/sq. ft. & 22.00 & 22.00 & 22.00 \\
\hline \hline O\&M costs, total & 6.95 & 6.73 & 6.73 \\
\hline Cleaning & 1.20 & 1.20 & 1.20 \\
\hline Repair/maintenance & 1.50 & 1.50 & 1.50 \\
\hline Utilities, total & 2.10 & 2.10 & 2.10 \\
\hline HVAC & 0.65 & 0.43 & 0.43 \\
\hline Electrical & 1.00 & 1.00 & 1.00 \\
\hline Water & 0.45 & 0.45 & 0.45 \\
\hline Roads/grounds & 0.35 & 0.35 & 0.35 \\
\hline Security & 0.50 & 0.50 & 0.50 \\
\hline Administrative & 1.30 & 1.30 & 1.30 \\
\hline \hline Fixed costs & 2.75 & 2.75 & 2.75 \\
\hline \hline Summary & & & 22.00 \\
\hline Gross income & 22.00 & -6.73 & -6.73 \\
\hline minus operating expenses & -6.95 & -2.75 & -2.75 \\
\hline minus fixed expenses & -2.75 & 12.52 & 12.52 \\
\hline \hline Net operating income & 12.30 & -8.57 & -8.42 \\
\hline minus debt service & -8.35 & 3.95 & 4.10 \\
\hline \hline Building owner's residual & 3.95 & & \\
\hline income & & & 22.00 \\
\hline
\end{tabular}




\section{REFERENCES}

Barkham, Richard, and David Geltner. 1993. "Price Discovery and Efficiency in American and British Property Markets." Real Estate Research Institute Discussion Paper.

Bayer, C. W., S. A. Crow, and J. Fischer. 1999. Causes of Indoor Air Quality Problems in Schools: Summary of Scientific Research. Report prepared for U.S. Department of Energy, January.

Brennan, Henry H. "Architectural Office Design: From Programming through Construction," in John Robert White, ed. in chief, The Office Building; From Concept to Investment Reality. Chicago: American Society of Real Estate Counselors and the Society of Industrial and Office Realtors, pp. 238-263.

Brown, Marilyn A. 2001. "Market Failures and Barriers as a Basis for Clean Energy Policies," Energy Policy, vol. 29, number 14, November 2001.

BOMA. 2000a. BOMA Pulse. BOMA International Research Department, June.

BOMA. 2000b. 2000 BOMA Experience Exchange Report. Washington, D.C.: Building Owners and Managers Association International.

Building Owners and Managers Association (BOMA) International and ULI-the Urban Land Institute. 1999. What Office Tenants Want: 1999 BOMA/ULI Office Tenant Survey Report. Washington, D.C.: BOMA International and ULI-the Urban Land Institute.

Cebon, Peter B. 1992. “"Twixt Cup and Lip; Organizational Behaviour, Technical Prediction and Conservation Practice," Energy Policy 20: 802-814.

Chapman, Robert E., and Roderick Rennison. 1998. An Approach for Measuring Reductions in Operations, Maintenance, and Energy Costs: Baseline Measures of Construction Industry Practices for the National Construction Goals. NISTIR 6185. Gaithersburg, Md.: National Institute of Standards and Technology, July.

Chao, Mark, David B. Goldstein, and Thomas P. Conlon. 1998. "Energy Costs and Valuation of Commercial Properties by Appraisers and Lenders," in 1998 ACEEE Summer Study on Energy Efficiency in Buildings Proceedings. Vol.4. Commercial Buildings: Program Design, Implementation, and Evaluation. Washington, D.C.: ACEEE, pp. 4.63-4.70.

Coverdale, Glen E. 1993. "Office Mortgage Financing from the Lender's Viewpoint," in John Robert White, ed. in chief, The Office Building; From Concept to Investment 
Reality. Chicago: American Society of Real Estate Counselors and the Society of Industrial and Office Realtors, pp. 434-442.

DeCanio, Stephen J. 1998. "The Efficiency Paradox: Bureaucratic and Organizational Barriers to Profitable Energy-Saving Investments," Energy Policy 26: 441-454.

DeCanio, Stephen J. 1993. "Barriers within Firms to Energy-Efficient Investments," Energy Policy 21: 906-914.

DeCanio, Stephen J., and William E. Watkins. 1998. "Investment in Energy Efficiency: Do the Characteristics of Firms Matter?" Review of Economics and Statistics 80: 95-107.

Fisher, Jeffrey D. 1992. "Integrating Research on Markets for Space and Capital," Journal of the American Real Estate and Urban Economics Association 20: 161-180.

Graff, Richard A., and James R. Webb. 1997. "Agency Costs and Inefficiency in Commercial Real Estate," Journal of Real Estate Portfolio Management 3: 19-36.

Hamilton, James D. 1996. "Analysis of the Transmission of Oil Price Shocks through the Macroeconomy." Paper presented at the DOE Conference, "International Energy Security: Economic Vulnerability to Oil Price Shocks, Washington, D.C., October 1996.

Hooker, Mark A. 1996. "Exploring the Robustness of the Oil Price-Macroeconomy Relationship: Empirical Specifications and the Role of Monetary Policy." Paper presented at the DOE Conference, "International Energy Security: Economic Vulnerability to Oil Price Shocks, Washington, D.C., October 1996.

Hendershott, Patric H. 1996. "Rental Adjustment and Valuation in Overbuilt Markets: Evidence from the Sydney Office Market," Journal of Urban Economics 39: 51-67.

Hendershott, Patric H., Colin M. Lizieri, and George A. Matysiak. 1999. "The Workings of the London Office Market," Real Estate Economics 27: 365-387.

Heschong, Lisa, Douglas Mahone, Kalpana Juttiah, Nehemiah Stone, Cathy Chappell, Jon McHugh, and Jackie Burton. 1999a. Skylighting and Retail Sales: An Investigation into the Relationship between Daylighting and Human Performance. Report prepared for Pacific Gas \& Electric Corporation. San Francisco: Pacific Gas \& Electric. (http://www.h-m-g.com/Daylighting/daylighting_and_productivity.htm)

Heschong, Lisa, Douglas Mahone, Kalpana Juttiah, Nehemiah Stone, Cathy Chappell, Jon McHugh, and Jackie Burton. 1999b. Daylighting in Schools: An Investigation into the Relationship between Daylighting and Human Performance. Report prepared for Pacific Gas \& Electric Corporation. San Francisco: Pacific Gas \& Electric. (http://www.h-m-g.com/Daylighting/daylighting_and_productivity.htm) 
Hillebrandt, Patricia M. 1985. Economic Theory and the Construction Industry. $2^{\text {nd }}$ Edition. London: Macmillan.

Howarth, Richard B., and Bo Andersson. 1993. "Market Barriers to Energy Efficiency," Energy Policy 21: 262-272.

Jaffe, Adam B., and Robert N. Stavins. 1994. "The Energy Paradox and the Diffusion of Conservation Technology," Resource and Energy Economics 16: 91-122.

Kolderup, Erik, Anthony Bernheim, Virginia Lew, Brian Liebel, John Raeber, Aditi Raychoudhury, and Steven Taylor. "Reference specifications for Energy and Resource Efficiency," in 2000 ACEEE Summer Study on Energy Efficiency in Buildings Proceedings. Vol. 3. Commercial Buildings: Technologies, Design, and Performance Analysis. Washington, D.C.: ACEEE, 2000, pp. 3.197-3.202.

Koomey, Jonathan G. 1990. Energy Efficiency Choices in New Office Buildings: An Investigation of Market Failures and Corrective Policies. Ph.D. dissertation, Energy and Resources, University of California at Berkeley.

Koomey, Jonathan G., and Alan H. Sanstad. 1994. "Technical Evidence for Assessing the Performance of Markets Affecting Energy Efficiency," Energy Policy 22: 826-832.

Koomey, Jonathan G., Alan H. Sanstad, and Leslie J. Shown. 1995. "Energy-Efficient Lighting: Market Data, Market Imperfections, and Policy Success," Contemporary Economic Policy 14: 98-111.

Kulakowski, Susan L. 1999. Large Organizations' Investments in Energy-Efficient Building Retrofits. LBNL-40895. Berkeley, Calif.: Lawrence Berkeley National Laboratory, March.

Lentz, George H., and K.S. Maurice Tse. 1999. "Supply Adjustments to Demand Shocks in the Commercial Real Estate Market," Real Estate Economics 27: 231-262.

Lockwood, Larry J., and Ronald C. Rutherford. 1996. "Determinants of Industrial Property Value,” Real Estate Economics 24: 257-272.

Longstreth, Molly, Anne R. Coveny, and Jean S. Bowers. 1984. "Conservation Characteristics Among Determinants of Residential Property Value," Journal of Consumer Research 11: 564-571.

Lovejoy, George M., Jr. 1993. "Executive Office Building Management," in John Robert White, ed. in chief, The Office Building; From Concept to Investment Reality. Chicago: American Society of Real Estate Counselors and the Society of Industrial and Office Realtors, pp. 487-507. 
Lovins, Amory B., and L. Hunter Lovins. 1991. "Least-Cost Climatic Stabilization," Annual Review of Energy and the Environment 16: 433-531.

Mann, Thorbjoern. 1992. Building Economics for Architects. New York: Van Nostrand Reinhold.

Mills, Edwin S. 1995. "Crisis and Recovery in Office Markets," Journal of Real Estate Finance and Economics 10: 49-62.

Mills, Edwin S. 1992. "Office Rent Determinants in the Chicago Area," Journal of the American Real Estate and Urban Economics Association 20: 273-289.

Mills, Edwin S., and Ronald Simenauer. 1996. "New Hedonic Estimates of Regional Constant Quality House Prices," Journal of Urban Economics 39: 209-215.

Montgomery, Michael R. 1995. “'Time-to-Build' Completion Patterns for Nonresidential Structures, 1961-1991," Economics Letters 48: 155-163.

Morton, Ralph, and David Jaggar. 1995. Design and the Economics of Building. London: E and FN Spon.

National Academy of Sciences. 1992. Policy Implications of Greenhouse Warming: Mitigation, Adaptation, and the Science Base. Washington, D.C.: National Academy Press.

Palmquist, Raymond B. 1984. "Estimating the Demand for the Characteristics of Housing," Review of Economics and Statistics 66: 394-404.

Park, William R., and Wayne B. Chapin, Jr. 1992. Construction Bidding: Strategic Pricing for Profit. New York: John Wiley \& Sons.

Parker, Donald E., and Alphonse J. Dell'Isola. 1991. Project Budgeting for Buildings. New York: Van Nostrand Reinhold.

Postrel, Virginia. 2001. "Can Good Looks Guarantee a Product's Success?," The New York Times, July 12.

http://www.nytimes.com/2001/07/12/business/companies/12SCEN.html?ex=995956067\& ei $=1 \&$ en $=528$ efd 0152775358

Reed, John H., Andrew D. Oh, and Nicholas P. Hall. 2000. "The Structure and Operation of the Commercial Building Market," 2000 ACEEE Summer Study on Energy Efficiency in Buildings, Vol. 4. Commercial Buildings: Program Design, Implementation, and Evaluation. Washington, D.C.: American Council for an EnergyEfficient Economy, pp. 4.267-4.282. 
Rosen, Sherwin. 1974. "Hedonic Prices and Implicit Markets: Product Differentiation in Pure Competition," Journal of Political Economy 82: 34-55.

Rosenberg, Sidney B., and John B. Corgel. 1990. "Agency Costs in Apartment Property Management Contracts," Journal of the American Real Estate and Urban Economics Association 18: 184-201.

Ritz, George J. 1994. Total Construction Project Management. New York: McGrawHill.

Ronco, William C., and Jean S. Ronco. 1996. Partnering Manual for Design and Construction. New York: McGraw-Hill.

Sai-Chew, Dick, Loghman Azar, Marion Fraser, and Craig Montross. "Architectural Conservation Technologies," in 2000 ACEEE Summer Study on Energy Efficiency in Buildings Proceedings. Vol.4. Commercial Buildings: Program Design, Implementation, and Evaluation. Washington, D.C.: ACEEE, 2000, pp. 4.319-4.330.

Shama, A. 1983. "Energy Conservation in U.S. Buildings, Solving the High Potential/Low Adoption Paradox from a Behavioral Perspective," Energy Policy 11, No. 2: $148-167$.

Sivitanidou, Rena. 1995. "Urban Spatial Variations in Office-Commercial Rents: The Role of Spatial Amenities and Commercial Zoning," Journal of Urban Economics 38: 2349.

Sivitanidou, Rena. 1996. "Do Office-Commercial Firms Value Access to Service Employment Centers? A Hedonic Value Analysis within Polycentric Los Angeles," Journal of Urban Economics 40: 125-149.

Sivitanidou, Rena, and Petros Sivitanides. 2000. "Does the Theory of Irreversible Investments Help Explain Movements in Office-Commercial Construction?" Real Estate Economics 28: 623-661.

Sivitanidou, Rena, and William C. Wheaton. 1992. "Wage and Rent Capitalization in the Commercial Real Estate Market,” Journal of Urban Economics 31: 207-229.

Steele, Robert A. and Kenneth H. Barry. 1993. "The Financial Structuring of Office Investments: Debt and Equity," in John Robert White, ed. in chief, The Office Building; From Concept to Investment Reality. Chicago: American Society of Real Estate Counselors and the Society of Industrial and Office Realtors, pp. 413-433.

Vandell, K.D., and J.S. Lane. 1989. "The Economics of Architectural and Urban Design: Some Preliminary Findings," Journal of the American Real Estate and Urban Economics Association 17: 235-260. 
Webb, R. Brian, Mike Miles, and David Guilkey. 1992. “Transactions-Driven Commercial Real Estate Returns: The Panacea to Asset Allocation Models?" Journal of the American Real Estate and Urban Economics Association 20: 325-357.

Wheaton, William C., and Raymond G. Torto. 1994. "Office Rent Indices and Their Behavior over Time,” Journal of Urban Economics 35: 121-139.

Whyman, Christopher J. 1993. "Successful Office Building Operations," in John Robert White, ed. in chief, The Office Building; From Concept to Investment Reality. Chicago: American Society of Real Estate Counselors and the Society of Industrial and Office Realtors, pp. 508-528.

Wright, Roger, Marian Brown, Douglas Mahone, Ramona Peet, and Pete Jacobs. "The California Statewide Baseline Study of the Nonresidential New Construction Market," in 2000 ACEEE Summer Study on Energy Efficiency in Buildings Proceedings. Vol. 3. Commercial Buildings: Technologies, Design, and Performance Analysis. Washington, D.C.: ACEEE, 2000, pp. 3.373-3.381. 


\section{INTERNAL DISTRIBUTION}

1. J. B. Berry

2. L. G. Berry

3. M. A. Brown

4. J. E. Christian

5. T. R. Curlee

6. J. F. Eisenberg

7. P. D. Fairchild

8. S. G. Hildebrand

9. P. J. Hughes
10. M. McDonald

11. R. M. Lee

12. M. Schweitzer

13. R. B. Shelton

14.00B. E. Tonn

15-17. ESD Library

18. ORNL Central Research Library

19. ORNL Laboratory Records-RC 
